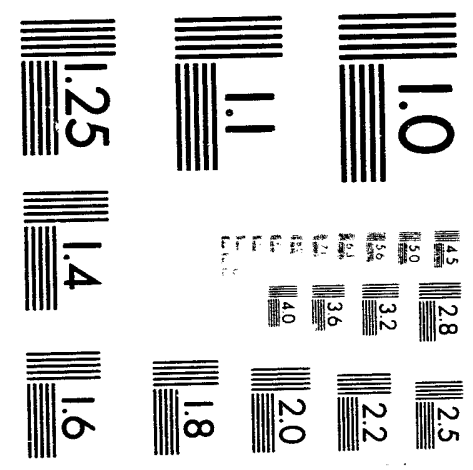



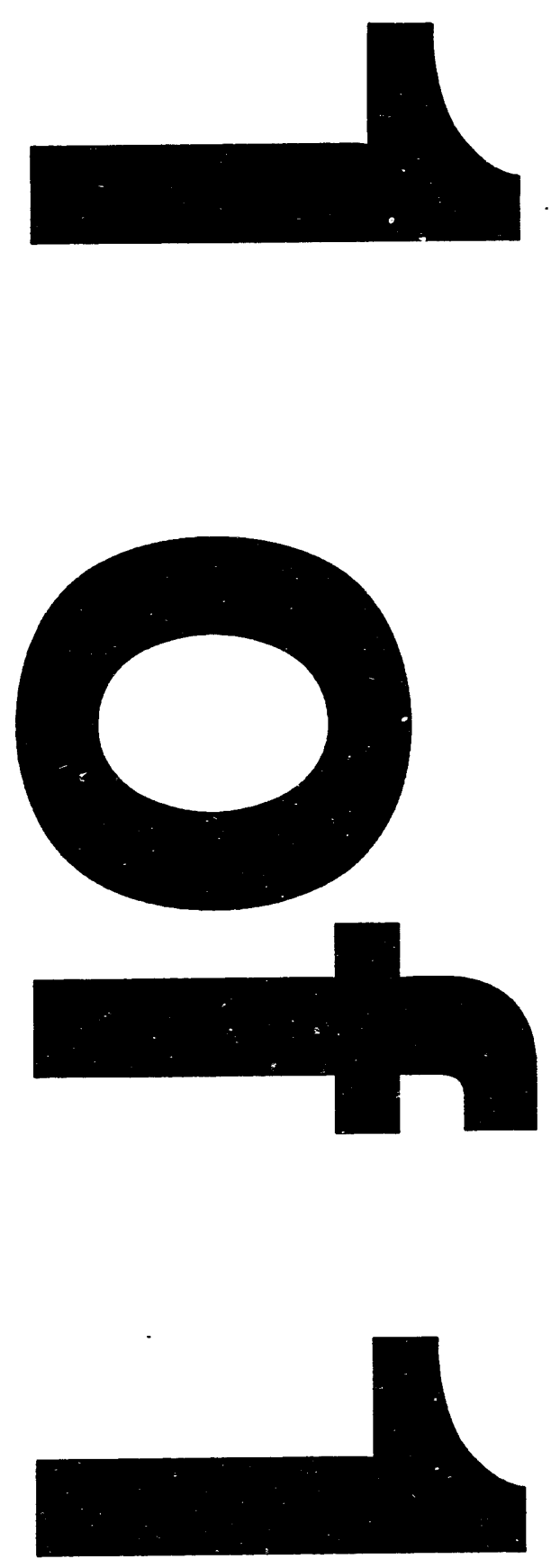


\title{
A Literature Review of Actinide-Carbonate Mineral Interactions
}

\author{
Daniel L. Stout \\ Department of Geological Sciences \\ University of Missouri-Columbia \\ Columbia, MO 65211, USA \\ Susan A. Carroll \\ Lawrence Livermore National Laboratory \\ Earth Sciences Department \\ Livermore, CA 94550, USA
}

\begin{abstract}
Chemical retardation of actinides in groundwater systems is a potentially important mechanism for assessing the performance of the Waste Isolation Pilot Plant (WIPP), a U.S. Department of Energy facility intended to demonstrate safe disposal of transuranic waste. Rigorous estimation of chemical retardation during transport through the Culebra Dolomite, a water-bearing unit overlying the WIPP, requires a mechanistic understanding of chemical reactions between dissolved elements and mineral surfaces. This report represents a first step toward this goal by examining the literature for pertinent experimental studies of actinide-carbonate interactions. A summary of existing models is given, along with the types of experiments on which these models are based. Articles pertaining to research into actinide interactions with carbonate minerals are summarized. Select articles involving trace element-carbonate mineral interactions are also reviewed and may serve as templates for future research. A bibliography of related articles is included. Americium(III), and its nonradioactive analog neodymium(III), partition strongly from aqueous solutions into carbonate minerals. Recent thermodynamic, kinetic, and surface studies show that neodymium is preferentially removed from solution, forming a $\mathrm{Nd}-\mathrm{Ca}$ carbonate solid solution. Neptunium(V) is rapidly removed from solution by carbonates. Plutonium incorporation into carbonates is complicated by multiple oxidation states. Little research has been done on the radium(II) and thorium(IV) carbonate systems. The removal of uranyl ion from solution by calcite is limited to monolayer surface coverage by both the large size of the uranyl species and by carbonate complexation.
\end{abstract}




\section{FOREWORD}

This document was prepared in support of the Sandia National Laboratories (SNL) research effort for the Waste Isolation Pilot Plant (WIPP). The WIPP is a U.S. Department of Energy facility intended to demonstrate the safe disposal of transuranic nuclear waste; SNL is the scientific advisor to the WIPP.

One of the current driving scenarios for WIPP performance assessment is human intrusion, where one or several boreholes are drilled into or through the waste panel(s) in the WIPP after closure and decommissioning. Under human intrusion scenarios, dissolved or colloidal actinides may be transported up a breach borehole to the Culebra Dolomite Member of the Rustler Formation, a dolomitic (calcium-magnesium carbonate) water-bearing unit overlying the WIPP Site. Should this scenario occur, actinides could be transported through the Culebra and might eventually reach the accessible environment. One potentially important mechanism for reducing this transport is chemical interaction between the actinides and the mineral phases in the Culebra, which could effectively immobilize some fraction of the actinides via incorporation into carbonate minerals, and thus reduce release from the Culebra. This report summarizes information available in the literature regarding actinide-carbonate interactions; it will serve as a preliminary guide for experimental studies for chemical retardation at the WIPP. 


\section{CONTENTS}

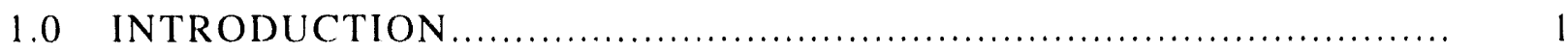

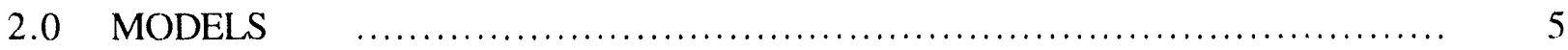

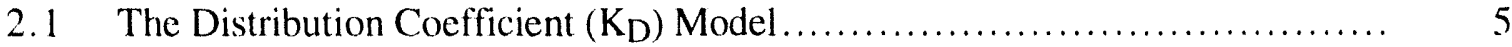

2.2 The Homogeneous Partition Coefficient (D) Model ....................... 5

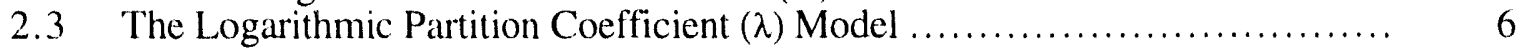

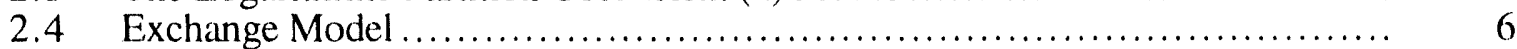

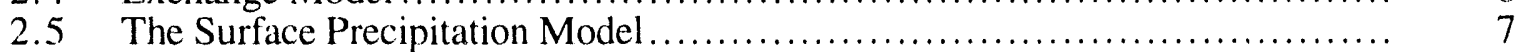

2.6 Dynamic Feedback .............................................. 10

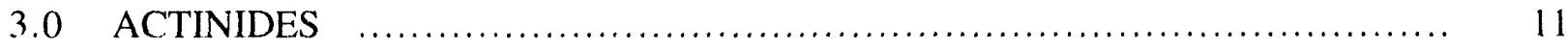

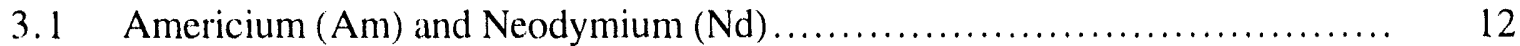

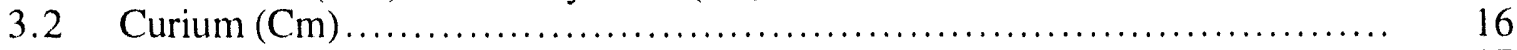

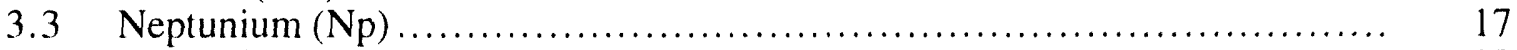

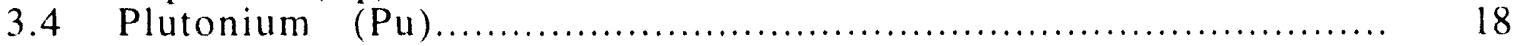

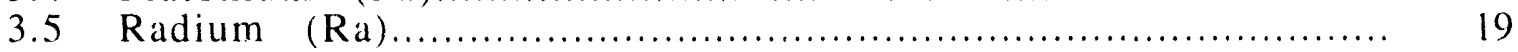

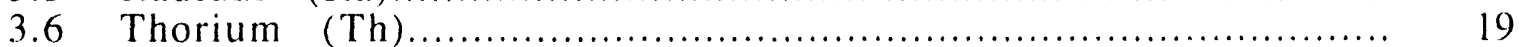

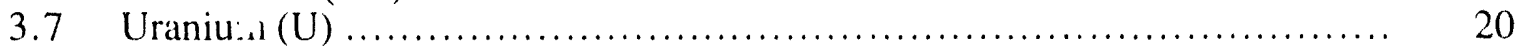

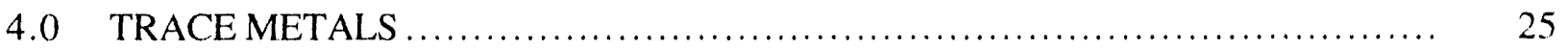

4.1 Comparative Studies ............................................ 25

4.2 Single Element Studies......................................... 28

4.2.1 Cadmium: Studies of the Aqueous Phase............................ 28

4.2.2 Cadmium: Study of the Solid Phase................................... 31

4.2.3 Zinc: Studies of the Aqueous Phase ............................. 32

4.2.4 Zinc: Study of the Solid Phase .............................. 34

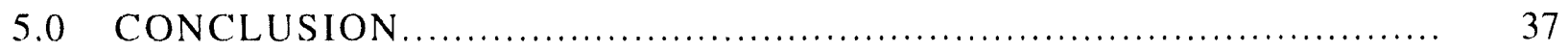

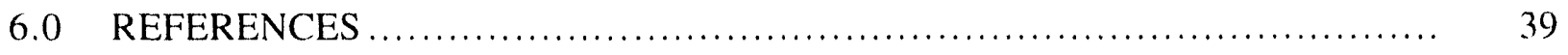

$\begin{array}{ll}\text { APPENDIX A: } & \text { BIBLIOGRAPHY OF ACTINIDE SPECIATION, } \\ & \text { COMPLEXATION, AND SOLUBILITY STUDIES } \ldots \ldots \ldots \ldots \ldots \ldots \ldots \text { A-1 }\end{array}$

APPENDIX B: $\quad$ BIBLIOGRAPHY OF TRACE METAL

SORPTION/COPRECIPITATION STUDIES ................... B- 1 


\section{Figures}

2-1 Sorption Isotherm Behavior for the Surface Precipitation Model..$\ldots \ldots \ldots \ldots \ldots \ldots$.

\section{Tables}

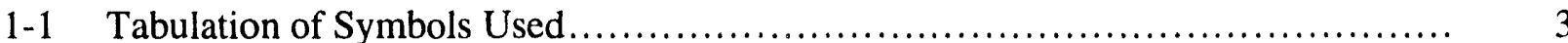

3-1 Summary of Reviewed Actinide-Carbonate Mineral Research....................... 11

4-1 Summary of Reviewed Trace Metal-Carbonate Mineral Research................... 27 


\subsection{INTRODUCTION}

The geochemistry of actinides is a topic of growing scientific attention as researchers seek more rigorous and predictive chemical migration models. In order to predict the overall safety of radioactive waste disposal, it is imperative that radionuclide-mineral-water interactions be understood within a thermodynamic and kinetic framework. In the past, much research focused on the generation of empirical parameters such as distribution coefficients and kinetic data that rarely have predictive value beyond the conditions of the experiment. Future studies should include thermodynamic and kinetic experiments, as well as observations of the aqueous and solid phases, to reveal the mechanisms controlling the mobility of radionuclides in the geosphere.

This review summarizes a significant portion of the actinide-carbonate studies that are available in major geochemical journals. However, it must be noted that few studies have been carried out within a rigorous thermodynamic or kinetic framework. No attempt is made here to compare the results of the different studies. The first part of this report reviews sorption and coprecipitation models commonly applied to mineral-water interactions. The main body summarizes the various actinide-carbonate studies, concentrating on methodology, models, and results. Following the actinide reviews are a few select trace element-carbonate studies that may serve as guidelines for future research in the actinide-carbonate system. Finally, a bibliography of related actinide and trace element-carbonate studies is provided.

The literature contains a great deal of ambiguity concerning the terms sorption, absorption, adsorption, precipitation, coprecipitation, and solid solution. Sorption is a broad term that encompasses three different processes: (1) absorption that involves the diffusion of an aqueous solute into a porous solid phase; (2) adsorption that involves ions being held at a solid interface by electrostatic forces (non-specific adsorption or physisorption) and/or the chemical attraction of coordinatively unsatisfied ions at the surface (specific adsorption or chemisorption); and (3) surface precipitation, which occurs as a surface phase grows by propagation of a molecular unit that repeats itself outward into the solution. Surface precipitation may also include the formation of an ordered solid solution. Coprecipitates or solid solutions may form when a trace ion occupies structural sites within a mineral's lattice, or more rarely when the ion occupies non-lattice positions. The term coprecipitation is generally used to describe precipitation of a mixed phase from solutions supersaturated with respect to both the major and trace solid end-member components. However, solid solution development is not limited to such conditions; solid solutions may form by a number of processes, including solid-state diffusion of an adsorbed ion 
into a substrate, the exchange of ions at an interface, and the incorporation of trace ions during recrystallization.

Symbols used throughout the text are listed in Table 1-1. 
Table 1-1. Tabulation of Symbols Used

\begin{tabular}{|c|c|}
\hline [i] & concentration of aqueous species i \\
\hline$\{i\}$ & activity of aqueous species i \\
\hline$\gamma_{i}$ & activity coefficient for aqueous species or solid component i \\
\hline $\mathrm{X}_{\mathrm{i}}$ & mole fraction of component $\mathrm{i}$ \\
\hline $\mathrm{X}_{\mathrm{i}}^{*}$ & mole fraction of component $i$ at the mineral surface \\
\hline Me & radionuclide or trace metal \\
\hline $\mathrm{Me}_{\mathrm{T}}$ & total radionuclide or trace metal \\
\hline Mc & major cation (usually $\mathrm{Ca}, \mathrm{Mg}$, etc.) \\
\hline$\Gamma$ & moles $\mathrm{Me}_{\text {iddsorbed }} /$ moles $\mathrm{Mc}$ \\
\hline$>\mathrm{Me}$ & surface species Me \\
\hline $\mathrm{K}_{\mathrm{sp}}$ & solubility product \\
\hline $\mathrm{K}_{\mathrm{D}}$ & distribution coefficient \\
\hline D & homogenous partition coefficient \\
\hline$\lambda$ & logarithmic partition coefficient \\
\hline $\mathrm{K}_{\mathrm{ex}}$ & thermodynamic exchange constant \\
\hline${ }^{\mathrm{c}} \mathrm{K}_{\mathrm{ex}}$ & conditional exchange constant \\
\hline $\mathrm{K}_{\mathrm{ex}}^{*}$ & thermodynamic surface exchange constant \\
\hline $\mathrm{K}_{\mathrm{idds}}$ & adsorption constant \\
\hline $\mathrm{S}_{\mathrm{T}}$ & total available surface sites \\
\hline DI & distilled and/or deionized water \\
\hline SW/ASW & sea water / artificial sea water \\
\hline GW/AGW & ground water / artificial ground water \\
\hline AES & Auger electron spectroscopy \\
\hline $\mathrm{BEI}$ & backscattered electron imagery \\
\hline EDS & energy dispersive spectroseopy \\
\hline LEED & low energy electron diffraction \\
\hline RBS & Rutherford backscaltering spectroseopy \\
\hline SEM & scanning electron microscopy \\
\hline XPS & $X$-ray photoelectron spectroscopy \\
\hline
\end{tabular}




\subsection{MODELS}

\subsection{The Distribution Coefficient $\left(K_{D}\right)$ Model}

Until the early 1980s, sorption modeling focused on the generation of empirical distribution coefficients, $K_{D}$, defined as:

$$
\mathrm{K}_{\mathrm{D}}=\frac{[\mathrm{Me}]_{\text {solid }}}{[\mathrm{Me}]_{\text {solution }}}
$$

where $[\mathrm{Me}]$ represents the trace element concentration in the solid or solution phase. $\mathrm{K}_{\mathrm{D}}$ values are highly conditional upon $\mathrm{pH}$, mineralogy, available surface area, free metal concentrations, and complexing ligands (see for example Novak, 1992). Thus, the distribution coefficient effectively describes only the experiment from which it is derived. Little information for discriminating the processes at work (e.g., precipitation, adsorption, diffusion) may be assessed, and predictive value is minimal. Unless otherwise specified, $K_{D}$ values reported in this review are dimensionless.

\subsection{The Homogeneous Partition Coefficient (D) Mode!}

If a solid phase (a pure solid or a solid solution) is homogeneous and in equilibrium with an aqueous phase, the partitioning of the components between the two phases defines the homogeneous or Berthelot-Nernst partition coefficient, D, which is defined by McIntire (1963) as:

$$
\mathrm{D}=\frac{\left(\frac{[\mathrm{Me}]}{[\mathrm{Mc}]}\right)_{\text {solid }}}{\left(\frac{[\mathrm{Me}]}{[\mathrm{Mc}]}\right)_{\text {solution }}}
$$

The numerator is the concentration ratio of the trace component (Me) to the major component $(\mathrm{Mc})$ in the solid phase, and the denominator is the same ratio for the accompanying solution. $\mathrm{D}$ is a dimensionless quantity. The homogeneous partition coefficient has generally been used to describe coprecipitation. If $\mathrm{D}$ is greater than unity, the precipitate is enriched in the trace component relative to the solution. However, several investigators have shown that the distribution of trace elements in carbonates is controlled by kinetic reactions (see for example Davis et al., 1987; Franklin and Morse, 1982; Lorens, 1981; McBride, 1979; Pingitore, 1986). Therefore, the partition coefficient is generally not a thermodynamic constant and will vary with changes in the composition of the system. 


\subsection{The Logarithmic Partition Coefficient $(\lambda)$ Model}

The Doerner-Hoskins, or logarithmic partition coefficient, $\lambda$, is defined as:

$$
\lambda=\frac{\log \left(\frac{[\mathrm{Me}]_{\mathrm{i}}}{[\mathrm{Me}]_{\mathrm{f}}}\right)}{\log \left(\frac{[\mathrm{Mc}]_{\mathrm{i}}}{[\mathrm{Mc}]_{\mathrm{f}}}\right)}
$$

where the numerator and denominator are the $\log$ ratios of the initial and final aqueous concentrations of the trace and major elements, respectively (McIntire, 1963). As the solution composition changes during precipitation, a heterogeneous distribution of the trace component occurs in the solid phase. Solid-state diffusion is generally regarded as too slow to maintain equilibrium between the interior of the crystal and the aqueous phase at earth-surface temperatures and pressures. The rate of crystallization, and hence the degree of supersaturation, affects the observed value of $\lambda$. Like the homogeneous partition coefficient, the logarithmic partition coefficient is not a thermodynamic constant and will vary with changes in the system.

\subsection{Exchange Model}

The exchange model is founded on the thermodynamics of both the aqueous and solid phases. Regardless of the mechanism of solid solution formation, the system may be defined in terms of the activities of the components. If a solid solution is in equilibrium with an aqueous phase, the exchange of cations between the solid (using calcium carbonate, for example) and the aqueous phase may be described as:

$$
\mathrm{Me}^{2+}+\mathrm{CaCO}_{3}(\mathrm{~s}) \leftrightarrow \mathrm{MeCO}_{3}(\mathrm{~s})+\mathrm{Ca}^{2+}
$$

The corresponding thermodynamic exchange constant is defined as:

$$
\mathrm{K}_{\mathrm{ex}}=\frac{\left\{\mathrm{MeCO}_{3}(\mathrm{~s})\right\}\left\{\mathrm{Ca}^{2+}\right\}}{\left\{\mathrm{CaCO}_{3}(\mathrm{~s})\right\}\left\{\mathrm{Me}^{2+}\right\}}
$$

$\mathrm{K}_{\mathrm{ex}}$ is equal to the ratio of the pure end-member solubility products:

$$
\mathrm{K}_{\mathrm{ex}}=\frac{\mathrm{K}_{\mathrm{sp}}\left(\mathrm{CaCO}_{3}(\mathrm{~s})\right)}{\mathrm{K}_{\mathrm{sp}}\left(\mathrm{MeCO}_{3}(\mathrm{~s})\right)}
$$

where $\mathrm{K}_{\mathrm{sp}}\left(\mathrm{CaCO}_{3}(\mathrm{~s})\right)$ and $\mathrm{K}_{\mathrm{sp}}\left(\mathrm{MeCO}_{3}(\mathrm{~s})\right)$ are given by: 


$$
\begin{aligned}
& \mathrm{K}_{\mathrm{sp}}\left(\mathrm{CaCO}_{3}(\mathrm{~s})\right)=\frac{\left\{\mathrm{Ca}^{2+}\right\}\left\{\mathrm{CO}_{3}^{2-}\right\}}{\left\{\mathrm{CaCO}_{3}(\mathrm{~s})\right\}} \\
& \mathrm{K}_{\mathrm{sp}}\left(\mathrm{MeCO}_{3}(\mathrm{~s})\right)=\frac{\left\{\mathrm{Me}^{2+}\right\}\left\{\mathrm{CO}_{3}^{2-}\right\}}{\left\{\mathrm{MeCO}_{3}(\mathrm{~s})\right\}}
\end{aligned}
$$

for the reactions:

$$
\begin{aligned}
& \mathrm{CaCO}_{3(\mathrm{~s})} \leftrightarrow \mathrm{Ca}^{2+}+\mathrm{CO}_{3}^{2-} \\
& \mathrm{MeCO}_{3(\mathrm{~s})} \leftrightarrow \mathrm{Me}^{2+}+\mathrm{CO}_{3}^{2-}
\end{aligned}
$$

The ratio of Equations 7 and 8 yields Equation 6. If the solid solution is ideal (i.e., activity coefficients of the solid components are unity) $\mathrm{K}_{\mathrm{ex}}$ may be expressed by the equation:

$$
\mathrm{K}_{\mathrm{ex}}=\operatorname{IAP} \frac{\mathrm{X}_{\mathrm{Me}}}{\mathrm{X}_{\mathrm{Ca}}}
$$

where IAP represents the ion-activity product of the solution and $\mathrm{X}_{\mathrm{Me}}$ and $\mathrm{X}_{\mathrm{Ca}}$ are the mole fractions of the trace element and $\mathrm{Ca}$ in the solid. If the solid solution exhibits non-ideal behavior, activity coefficients of the solid trace and major elements, $\gamma_{i}$, must be taken into account, and Equation 11 becomes:

$$
\mathrm{K}_{\mathrm{ex}}=\operatorname{IAP} \frac{\mathrm{X}_{\mathrm{Me}} \gamma_{\mathrm{Me}}}{\mathrm{X}_{\mathrm{Ca}} \gamma_{\mathrm{Ca}}}
$$

\subsection{The Surface Precipitation Model}

Ions specifically adsorbed to a substrate have a tendency to form an insoluble compound with an ion of opposite charge on that surface. As more adsorbate is added, a solid component forms. A model describing the transition from adsorption to surface precipitation onto metal oxides was derived by Farley et al. (1985). Comans and Middelburg (1987) and Wersin et al. (1989) have applied this surface precipitation model to the carbonate mineral system. Three independent reactions and their corresponding equilibrium constants describe the trace metal-calcite system. The first two reactions represent the coprecipitation of $\mathrm{CaCO}_{3}-\mathrm{MeCO}_{3}$ :

$$
\mathrm{Ca}^{2+}+\mathrm{CO}_{3}^{2-} \leftrightarrow \mathrm{CaCO}_{3}(\mathrm{~s})
$$




$$
\mathrm{Me}^{2+}+\mathrm{CO}_{3}^{2-} \leftrightarrow \mathrm{MeCO}_{3}(\mathrm{~s})
$$

with their respective equilibrium solubility product expressions:

$$
\begin{aligned}
& \mathrm{K}_{\mathrm{sp}}\left(\mathrm{CaCO}_{3}(\mathrm{~s})\right)=\frac{\left\{\mathrm{Ca}^{2+}\right\}\left\{\mathrm{CO}_{3}^{2-}\right\}}{\left\{\mathrm{CaCO}_{3}(\mathrm{~s})\right\}} \\
& \mathrm{K}_{\mathrm{sp}}\left(\mathrm{MeCO}_{3}(\mathrm{~s})\right)=\frac{\left\{\mathrm{Me}^{2+}\right\}\left\{\mathrm{CO}_{3}^{2-}\right\}}{\left\{\mathrm{MeCO}_{3}(\mathrm{~s})\right\}}
\end{aligned}
$$

Equation 17 represents the adsorption of $\mathrm{Me}^{2+}$ at a calcite surface site, indicated by the $>$ symbol here:

$$
>\mathrm{CaCO}_{3}+\mathrm{Me}^{2+}+\mathrm{CO}_{3}^{2-} \leftrightarrow \mathrm{CaCO}_{3}(\mathrm{~s})+>\mathrm{MeCO}_{3}
$$

and may be described with the adsorption constant:

$$
\mathrm{K}_{\mathrm{ads}}=\frac{\left\{\mathrm{CaCO}_{3}(\mathrm{~s})\right\}\left[>\mathrm{MeCO}_{3}\right]}{\left[>\mathrm{CaCO}_{3}\right]\left\{\mathrm{Me}^{2+}\right\}\left\{\mathrm{CO}_{3}^{2-}\right\}}
$$

The adsorption of $\mathrm{Me}^{2+}$ in Equation 17 creates a new surface site and the underlying $\mathrm{CaCO}_{3}$ is incorporated into the bulk solid. The adsorption of $\mathrm{Ca}^{2+}$ onto $\mathrm{MeCO}_{3}(\mathrm{~s})$ may be represented by a combination of the three reactions resulting in a thermodynamic equilibrium constant equal to

$$
\frac{1}{\mathrm{~K}_{\mathrm{ads}} \mathrm{K}_{\mathrm{sp}}\left(\mathrm{CaCO}_{3}(\mathrm{~s})\right) \mathrm{K}_{\mathrm{sp}}\left(\mathrm{MeCO}_{3}(\mathrm{~s})\right)}
$$

The mass balance equations for the total Me concentration $\left(\mathrm{Me}_{\mathrm{T}}\right)$, total $\mathrm{Ca}$ concentration $\left(\mathrm{Ca}_{\mathrm{T}}\right)$, and the total surface reaction sites $\left(\mathrm{S}_{\mathrm{T}}\right)$ may be written as:

$$
\begin{aligned}
& \mathrm{Me}_{\mathrm{T}}=\left[\mathrm{Me}^{2+}\right]+\left[>\mathrm{MeCO}_{3}\right]+\left[\mathrm{MeCO}_{3}(\mathrm{~s})\right] \\
& \mathrm{Ca}_{\mathrm{T}}=\left[\mathrm{Ca}^{2+}\right]+\left[>\mathrm{CaCO}_{3}\right]+\left[\mathrm{CaCO}_{3}(\mathrm{~s})\right] \\
& \mathrm{S}_{\mathrm{T}}=\left[>\mathrm{CaCO}_{3}\right]+\left[>\mathrm{MeCO}_{3}\right]
\end{aligned}
$$

The conditional equilibrium constant, ${ }^{\mathrm{c}} \mathrm{K}_{\mathrm{ads}}$, may be obtained from the low concentration-surface coverage portion of the sorption isotherms shown in Figure 2-1 (Farley et al., 1985). Sorption isotherms typically exhibit an inflection point assumed to represent the saturation of surface sites, 


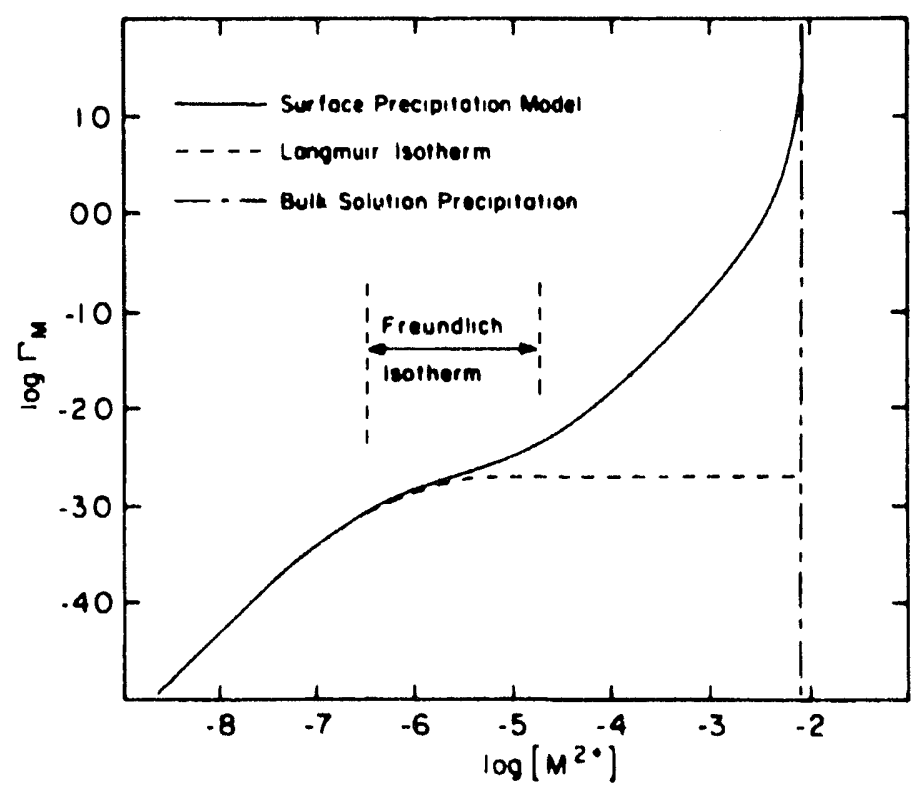

Figure 2-1. Sorption isotherm behavior for the surface precipitation model (Farley et al., 1985).

allowing estimation of $\mathrm{S}_{\mathrm{T}}$. The surface precipitation model predicts a smooth transition from adsorption to surface precipitation with increasing Me concentration. A line asymptotic to low concentration data represents adsorption far from saturation where:

$$
\Gamma_{\mathrm{Me}} \approx \frac{\left[\mathrm{MeCO}_{3}\right]}{\mathrm{Ca}_{\mathrm{T}}}
$$

Integration of the above equations allows calculation of the amount of $\mathrm{Me}^{2+}$ sorbed at any equilibrium $\mathrm{Me}^{2+}$ concentration, $\Gamma_{\mathrm{Me}}$, to be expressed by:

$$
\Gamma_{\mathrm{Me}}={ }^{c_{\mathrm{K}}} \mathrm{ads}_{\mathrm{T}} \frac{\mathrm{S}_{\mathrm{T}}}{\mathrm{Ca}_{\mathrm{T}}} \frac{\left[\mathrm{HCO}_{3}^{-}\right]}{\left[\mathrm{H}^{+}\right]}\left[\mathrm{Me}^{2+}\right]
$$

A major limitation of this model is its assumption that the sorption processes are at equilibrium. Numerous studies have shown that the kinetics of reaction control the concentration of trace elements in carbonate phases (see for example Davis et al., 1987; Franklin and Morse, 1982; Lorens, 1981; McBride, 1979; Pingitore, 1986). Also, the surface precipitation model assumes a solid solution forms only after available adsorption surface sites have been saturated. Other research has shown that this is not the case; solid solutions can form at low surface loadings (Davis et al., 1987; Stipp et al., 1992; Zachara et al., 1991). 


\subsection{Dynamic Feedback}

Wang and N'erino (1992) explain oscillatory zoning of trace elements in calcite as a result of an electrostatic feedback mechanism. Calcite growth releases $\mathrm{H}^{+}$, which accumulates at the calcite surface if growth is rapid enough. The buildup of positive charges repels adsorbing trace cations, and calcite growth accelerates due to the high $\mathrm{Ca}^{2+}$ chemical potential. Eventually, depletion of $\mathrm{Ca}^{2+}$ in the interfacial region occurs, slowing production of $\mathrm{H}^{+}$, and trace cations adsorb again. The possibility that trace element zoning in calcite results from the dynamics of growth makes it unnecessary to interpret oscillatory zoning in terms of drastic changes in solution composition. While the dynamic feedback model offers an explanation for the observed oscillatory zoning of trace elements, it has not been tested with experimental data. 


\subsection{ACTINIDES}

A summary of reviewed actinide-carbonate mineral research is provided in Table 3-1.

Table 3-1. Summary of Reviewed Actinide-Carbonate Mineral Research

\begin{tabular}{|c|c|c|c|c|c|c|}
\hline Author & Sorbate & Sorbent & $\begin{array}{l}\text { Background } \\
\text { solution }\end{array}$ & $\begin{array}{l}\text { Experiment } \\
\text { type }\end{array}$ & Value & Comments \\
\hline $\begin{array}{l}\text { Shanbhag and } \\
\text { Morse (1982) }\end{array}$ & Am(III) & $\begin{array}{c}\text { calcite } \\
\text { aragonite } \\
\text { biogenic carb. }\end{array}$ & $\begin{array}{c}\text { DI, } 0.7 \mathrm{M} \\
\mathrm{NaCl}-\mathrm{MgCl}_{2}, \\
\mathrm{ASW}, \mathrm{SW}\end{array}$ & $\begin{array}{c}\text { kinetic } \\
\text { distribution }\end{array}$ & $\mathrm{KD}_{\mathrm{D}}=10^{5.30}$ & $\begin{array}{c}{[\mathrm{Am}]=10^{-8.48}} \\
\mathrm{M}\end{array}$ \\
\hline $\begin{array}{c}\text { Higgo and Rees } \\
\text { (1986) }\end{array}$ & $\mathrm{Am}(\mathrm{III})$ & $\begin{array}{c}65 \% \text { calcite } \\
\text { sediment }\end{array}$ & SW & distribution & $\mathrm{K}_{\mathrm{D}}=10^{6.0}$ & $\begin{array}{l}\text { all }[\mathrm{Am}] \text { and } \\
\text { S/S ratios }\end{array}$ \\
\hline Allard (1984) & Am(III) & calcite & $\begin{array}{c}\text { AGW } \\
4 \mathrm{M} \mathrm{NaCl}\end{array}$ & distribution & $\begin{array}{l}\mathrm{K}_{\mathrm{D}}=10^{3.85} \\
\mathrm{~K}_{\mathrm{D}}=10^{4.47}\end{array}$ & $\begin{array}{l}\mathrm{pH} 6.5 \\
\mathrm{pH} 9.0\end{array}$ \\
\hline Dosch (1979) & Am(III) & dolomite & $\begin{array}{c}\text { AGW } \\
\mathrm{NaCl} \text { brine }\end{array}$ & distribution & $\begin{array}{l}\mathrm{K}_{\mathrm{D}}=10^{4.34} \\
\mathrm{~K}_{\mathrm{D}}=10^{3.41}\end{array}$ & $\begin{array}{c}\text { AGW } \\
\mathrm{NaCl} \text { brine }\end{array}$ \\
\hline $\begin{array}{l}\text { Dosch and Lynch } \\
\text { (1980) }\end{array}$ & $\mathrm{Am}(\mathrm{III})$ & $\begin{array}{c}\text { dolomite, } \\
\text { proto-dolomite }\end{array}$ & AGW & distribution & $\begin{array}{r}\mathrm{K}_{\mathrm{D}}=10^{3.30} \\
\text { to } 10^{4.30} \\
\end{array}$ & $\mathrm{n} / \mathrm{a}$ \\
\hline Carroll (1993) & $\mathrm{Nd}(\mathrm{III})$ & $\begin{array}{c}\text { calcite } \\
\text { aragonite }\end{array}$ & $\mathrm{NaHCO}_{3}$ & $\begin{array}{l}\text { exchange } \\
\text { kinetic } \\
\text { surface }\end{array}$ & $\begin{array}{l}\operatorname{Kex}=10^{0.84} \\
\operatorname{Kex}=10^{0.52}\end{array}$ & $\begin{array}{l}{[\mathrm{Nd}] \geq 10^{-4.5} \mathrm{M}} \\
{[\mathrm{Nd}] \leq 10^{-5.5} \mathrm{M}}\end{array}$ \\
\hline Carroll et al. (1992) & $\mathrm{Nd}$ (III) & calcite & $\mathrm{NaHCO}_{3}$ & surface & $\mathrm{n} / \mathrm{a}$ & $\begin{array}{c}\text { SEM, BEI, } \\
\text { EDS } \\
\end{array}$ \\
\hline $\begin{array}{c}\text { Mecherri et al. } \\
\text { (1990) }\end{array}$ & $\mathrm{Nd}(\mathrm{III})$ & calcite & DI & $\begin{array}{c}\text { kinetic } \\
\text { distribution }\end{array}$ & $\mathrm{K}_{\mathrm{D}}=10^{3.38}$ & {$[\mathrm{Nd}]=10^{-5.48} \mathrm{M}$} \\
\hline $\begin{array}{l}\text { Keeney-Kennicutt } \\
\text { and Morse (1984) }\end{array}$ & $\mathrm{NpO}_{2}{ }^{+}$ & $\begin{array}{c}\text { calcite } \\
\text { aragonite } \\
\text { carb. sediment }\end{array}$ & $\begin{array}{c}\mathrm{DI}, 0.7 \mathrm{M} \\
\mathrm{NaCl}-\mathrm{MgCl}_{2} \\
\mathrm{ASW}, \mathrm{SW}\end{array}$ & kinetic & $\mathrm{n} / \mathrm{a}$ & $\mathrm{n} / \mathrm{a}$ \\
\hline $\begin{array}{l}\text { Higgo and Rees } \\
(1986)\end{array}$ & $\mathrm{Np}(\mathrm{V})$ & $\begin{array}{c}65 \% \text { calcite } \\
\text { sediment } \\
\end{array}$ & $\mathrm{SW}$ & distribution & $\mathrm{K}_{\mathrm{D}}=10^{3.60}$ & $\begin{array}{c}{[\mathrm{Np}]=10^{-7.47} \mathrm{M}} \\
\text { all S/S ratios }\end{array}$ \\
\hline Allard (1984) & $\mathrm{Np}(\mathrm{V})$ & calcite & $\begin{array}{c}\text { AGW } \\
4 \mathrm{M} \mathrm{NaCl}\end{array}$ & distribution & $\begin{array}{l}\mathrm{K}_{\mathrm{D}}<10^{2.3} \\
\mathrm{~K}_{\mathrm{D}}=10^{3.60} \\
\end{array}$ & $\begin{array}{l}\text { pH } 6.5 \\
\text { pH } 9.0\end{array}$ \\
\hline $\begin{array}{c}\text { Ames and Rai } \\
(1978)\end{array}$ & $N p(V)$ & calcite & $\mathrm{n} / \mathrm{a}$ & distribution & $\mathrm{K}_{\mathrm{D}}=10^{3.70}$ & $\mathrm{n} / \mathrm{a}$ \\
\hline $\begin{array}{c}\text { Higgo and Rees } \\
\text { (1986) }\end{array}$ & $\mathrm{Pu}$ & $\begin{array}{l}65 \% \text { carbonate } \\
\text { sediment }\end{array}$ & SW & distribution & $\begin{array}{c}\mathrm{K}_{\mathrm{D}}=10^{2-2.3} \\
\mathrm{~K}_{\mathrm{D}}>10^{4}\end{array}$ & $\begin{array}{l}\text { high } S / S \text { ratios } \\
\text { low } S / S \text { ratios }\end{array}$ \\
\hline $\begin{array}{c}\text { Gromov \& Spitsyn } \\
(1974)\end{array}$ & $\mathrm{Pu}$ & $\begin{array}{c}\text { carbonate } \\
\text { sediment }\end{array}$ & SW & distribution & $\mathrm{K}_{\mathrm{D}}=10^{4.04}$ & $\mathrm{n} / \mathrm{a}$ \\
\hline $\begin{array}{c}\text { Ginzburg and } \\
\text { Maksimov (1975) }\end{array}$ & $\mathrm{Pu}(\mathrm{IV})$ & $\begin{array}{l}\text { carbonate } \\
\text { precipitates }\end{array}$ & DI & partition & $\mathrm{n} / \mathrm{a}$ & $\mathrm{n} / \mathrm{a}$ \\
\hline $\operatorname{Dosch}(1979)$ & $\mathrm{Pu}$ & dolomite & $\begin{array}{c}\text { AGW } \\
\mathrm{NaCl} \text { brine }\end{array}$ & distribution & $\begin{array}{l}\mathrm{K}_{\mathrm{D}}=10^{3.86} \\
\mathrm{~K}_{\mathrm{D}}=10^{3.32}\end{array}$ & $\begin{array}{c}\text { AGW } \\
\mathrm{NaCl} \text { brine }\end{array}$ \\
\hline $\begin{array}{c}\text { Dosch and Lynch } \\
\text { (1980) }\end{array}$ & $\mathrm{Pu}$ & $\begin{array}{c}\text { dolomite } \\
\text { proto-dolomite }\end{array}$ & AGW & distribution & $\begin{array}{r}\mathrm{K}_{\mathrm{D}}=10^{3.30} \\
\text { to } 10^{3.85} \\
\end{array}$ & $\mathrm{n} / \mathrm{a}$ \\
\hline
\end{tabular}


Table 3-1. Summary of Reviewed Actinide-Carbonate Mineral Research (continued)

\begin{tabular}{|c|c|c|c|c|c|c|}
\hline Author & Sorbate & Sorbent & $\begin{array}{c}\text { Background } \\
\text { solution }\end{array}$ & $\begin{array}{c}\text { Experiment } \\
\text { type }\end{array}$ & Value & Comments \\
\hline $\begin{array}{l}\text { Gnanapragasam } \\
\text { (1991) }\end{array}$ & $\mathrm{Ra}$ & $\begin{array}{l}\text { carbonate } \\
\text { precipitates }\end{array}$ & DI & partition & $1=10^{-1.89}$ & $\begin{array}{l}\mathrm{Ra}^{2+} / \mathrm{Ca}^{2+}= \\
10^{-6} \text { to } 10^{-9}\end{array}$ \\
\hline Carroll et al. (1992) & Th & calcite & $\mathrm{NaHCO}_{3}$ & surface & $\mathrm{n} / \mathrm{a}$ & SEM, BEI \\
\hline $\begin{array}{c}\text { Carroll and Bruno } \\
\text { (1991) }\end{array}$ & $\mathrm{U}(\mathrm{VI})$ & calcite & $\mathrm{NaHCO}_{3}$ & $\begin{array}{c}\text { kinetic } \\
\text { exchange }\end{array}$ & $\begin{array}{c}\mathrm{K} * \mathrm{ex}= \\
10^{-5.12 \pm 0.53}\end{array}$ & $\mathrm{n} / \mathrm{a}$ \\
\hline Carroll et al. (1992) & $\mathrm{U}(\mathrm{VI})$ & calcite & $\mathrm{NaHiCO}_{3}$ & surface & $\mathrm{n} / \mathrm{a}$ & $\begin{array}{c}\text { SEM, BEI, } \\
\text { RBS }\end{array}$ \\
\hline Morse et al. (1984) & $\mathrm{U}(\mathrm{VI})$ & $\begin{array}{c}\text { calcite } \\
\text { aragonite } \\
\text { biogenic carb. }\end{array}$ & $\begin{array}{l}\text { DI } \\
\text { SW }\end{array}$ & kinetic & $\mathrm{n} / \mathrm{a}$ & $\mathrm{n} / \mathrm{a}$ \\
\hline $\begin{array}{l}\text { Milton and Brown } \\
\text { (1987) }\end{array}$ & $\mathrm{U}(\mathrm{VI})$ & calcite & GW & kinetic & $\mathrm{n} / \mathrm{a}$ & $\mathrm{n} / \mathrm{a}$ \\
\hline $\begin{array}{c}\text { Kitano and Oomori } \\
\text { (1971) }\end{array}$ & $\mathrm{U}(\mathrm{VI})$ & $\begin{array}{l}\text { Mg-calcite } \\
\text { aragonite }\end{array}$ & $\mathrm{Ca}\left(\mathrm{HCO}_{3}\right)_{2}$ & partition & $\begin{array}{l}I=10^{-2} \text { to }-0.7 \\
=10^{-0.52 \text { to } 0}\end{array}$ & $\begin{array}{c}\text { calcite } \\
\text { aragonite }\end{array}$ \\
\hline
\end{tabular}

\subsection{Americium (Am) and Neodymium (Nd)}

Neodymium, commonly used as a chemical analog for americium, is included in this section.

Carroll (1993) studied the thermodynamics and kinetics of $\mathrm{Nd}-\mathrm{Ca}$ carbonate solid-solution formation. Three different types of kinetic experiments investigated the formation of a $\mathrm{Nd}-\mathrm{Ca}$ carbonate solid solution. The first set of experiments investigated the effects of initial aqueous $\mathrm{Nd}$ concentrations on solid solution kinetics. The second set explored the formation of a solid solution from near-saturation by reacting a Nd-carbonate with calcite. The third set studied the formation of a solid solution from a solution saturated with respect to $\mathrm{NdOHCO}_{3}(\mathrm{~s})$ and undersaturated with respect to calcite or aragonite. Batch reaction techniques were used for all three experiment types, and reaction times varied between 30 and 40 days.

The $\mathrm{Nd}-\mathrm{Ca}-\mathrm{CO}_{2}-\mathrm{H}_{2} \mathrm{O}$ system is somewhat unique in that $\mathrm{Nd}^{3+}$ has a smaller ionic radius and higher valence than $\mathrm{Ca}^{2+}$, and the solid solution occurs in the precipitated trace element phase rather than in the major phase. Aqueous $\mathrm{Ca}^{2+}$ and $\mathrm{Nd}^{3+}$ concentrations were controlled by the precipitation of a homogeneous $\mathrm{Nd}-\mathrm{Ca}$ solid solution from the bulk solution. The solid solution, as shown by the experimental results, was more stable (i.e., less soluble) than its pure endmember components. Two distinct Nd-rich morphologies were observed with scanning electron microscopy (SEM) and backscattered electron imagery (BEI): a submicron fibrous precipitate, and larger bladed crystals. Energy dispersive spectroscopy (EDS) analyses of the larger bladed 
crystals indicated that the $\mathrm{Nd}$-rich carbonate phases were homo-geneous solid solutions containing approximately eight mole-percent calcium. The solid solution was interpreted to be orthorhombic, as orthorhombic $\mathrm{NdOHCO}_{3}(\mathrm{~s})$, the stable $\mathrm{Nd}$-carbonate phase in the absence of $\mathrm{Ca}$, and $\mathrm{Ca}^{2+}$ substituted for $\mathrm{Nd}^{3+}$ in the precipitated trace element phase. In all likelihood, the bladed crystals formed by Ostwald ripening (Parks, 1990) at the expense of the small Nd-rich fibrous crystals.

The $\mathrm{Nd}-\mathrm{Ca}$ carbonate phase was modeled as a solid solution between aragonite and $\mathrm{NdOHCO}_{3}(\mathrm{~s})$, both of which have orthorhombic structures. The development of the solid solution may be described by the exchange reaction:

$$
\mathrm{CaCO}_{3}(\mathrm{~s})+\mathrm{Nd}^{3+}+\mathrm{H}_{2} \mathrm{O} \leftrightarrow \mathrm{NdOHCO}_{3}(\mathrm{~s})+\mathrm{Ca}^{2+}+\mathrm{H}^{+}
$$

and the corresponding equilibrium exchange constant, $\mathrm{K}_{\mathrm{ex}}$ :

$$
\mathrm{K}_{\mathrm{ex}}=\frac{\left\{\mathrm{NdOHCO}_{3}(\mathrm{~s})\right\}\left\{\mathrm{Ca}^{2+}\right\}\left\{\mathrm{H}^{+}\right\}}{\left\{\mathrm{CaCO}_{3}(\mathrm{~s})\right\}\left\{\mathrm{Nd}^{3+}\right\}}
$$

The exchange reaction equilibrium constant is also equal to the ratio of the pure end-members' solubility products:

$$
\mathrm{K}_{\mathrm{ex}}=\frac{\mathrm{K}_{\mathrm{sp}}(\text { aragonite })}{\mathrm{K}_{\mathrm{sp}}\left(\mathrm{NdOHCO}_{3}(\mathrm{~s})\right)}
$$

where:

$$
\begin{aligned}
& \mathrm{K}_{\mathrm{sp}}(\text { aragonite })=\frac{\left\{\mathrm{Ca}^{2+}\right\} \mathrm{pCO}_{2}(\mathrm{~g})}{\left\{\mathrm{H}^{+}\right\}^{2}\left\{\mathrm{CaCO}_{3}(\mathrm{~s})\right\}} \\
& \mathrm{K}_{\mathrm{sp}}\left(\mathrm{NdOHCO}_{3}(\mathrm{~s})\right)=\frac{\left\{\mathrm{Nd}^{3+}\right\} \mathrm{pCO}_{2}(\mathrm{~g})}{\left\{\mathrm{H}^{+}\right\}^{3}\left\{\mathrm{NdOHCO}_{3}(\mathrm{~s})\right\}}
\end{aligned}
$$

for the reactions:

$$
\begin{aligned}
& \mathrm{CaCO}_{3}(\mathrm{~s})+2 \mathrm{H}^{+} \leftrightarrow \mathrm{Ca}^{2+}+\mathrm{CO}_{2}(\mathrm{~g})+\mathrm{H}_{2} \mathrm{O} \\
& \mathrm{NdOHCO}_{3}(\mathrm{~s})+3 \mathrm{H}^{+} \leftrightarrow \mathrm{Nd}^{3+}+\mathrm{CO}_{2}(\mathrm{~g})+2 \mathrm{H}_{2} \mathrm{O}
\end{aligned}
$$

respectively. $\mathrm{K}_{\mathrm{ex}}$ equals $10^{-(0.60}$ for an orthorhombic $\mathrm{NdOHCO}_{3}(\mathrm{~s})$ and aragonite solid solution.

The solution compositions reached a steady state within 200 hours of reaction, but they did not reach equilibrium. The solid solution was non-ideal, as the substitution of $\mathrm{Ca}^{2+}$ for $\mathrm{Nd}^{3+}$ into orthorhombic $\mathrm{NdOHCO}_{3}(\mathrm{~s})$ resulted in a reduction of the unit-cell volume. It was not 
possible to determine the activity of the solid components; therefore, only conditional constants were calculated from the steady-state solution compositions. The conditional constant, defined as

$$
{ }^{c} K_{e x}=\frac{\left\{\mathrm{Ca}^{2+}\right\}\left\{\mathrm{H}^{+}\right\}}{\left\{\mathrm{Nd}^{3+}\right\}}
$$

equals the IAP of reaction 25 . The constant ${ }^{c} \mathrm{~K}_{\mathrm{ex}}$ equaled $10^{0.84}$ and $10^{0.52}$ for initial $\mathrm{Nd}^{3+}$ concentrations greater than or equal to $10^{-4.5} \mathrm{M}$ and less than or equal to $10^{-5.5} \mathrm{M}$, respectively. The conditional constant represents an upper limit for aqueous concentrations of $\mathrm{Nd}$. Similar values would be expected for Am(III).

Carroll et al. (1992) examined Nd(III)-calcite surface interactions with SEM, BEI, and EDS at $50^{\circ} \mathrm{C}$. Initial $\mathrm{Nd}^{3+}$ concentrations were below $10^{-3} \mathrm{M}$ in a background solution of $10^{-2.30} \mathrm{M}$ of $\mathrm{NaHCO}_{3}$. At initial Nd concentrations of $10^{-5.72} \mathrm{M}$, small fibrous Nd-rich crystals approximately $20 \mu \mathrm{m}$ in length precipitated at the calcite surface. At the moment the experiment was terminated, the calcite appeared to be reacting with the Nd-rich crystals, implying that the system had not reached equilibrium. At higher Nd concentrations, both fibrous and euhedral star-shaped crystals were observed on the calcite surface. The core and inner arms of the star-shaped crystals were $\mathrm{Nd}$ rich and increasingly $\mathrm{Ca}$-rich outward. Based on the BEI image and EDS analysis, it was clear that a Nd-Ca carbonate solid solution had formed.

Smith (1990) modeled Am(III) substitution into calcite based on lattice energy considerations. In order for substitution of the trivalent cation to occur, two $\mathrm{Am}^{3+}$ cations may substitute for three $\mathrm{Ca}^{2+}$ in the solid phase. The results of these calculations are that americium substitution in calcite is highly non-ideal and that very limited substitution is likely.

Shanbhag and Morse (1982) investigated the interactions of Am(III) with calcite and aragonite and stipulated that $\mathrm{Am}$ (III) may be used as a representative element for all trivalent actinides. Initial $\mathrm{Am}^{3+}$ concentrations ranged from $10^{-12}$ to $10^{-7} \mathrm{M}$. Background solutions included deionized water, $0.7 \mathrm{M} \mathrm{NaCl}$, a $0.7 \mathrm{M} \mathrm{NaCl}-\mathrm{MgCl}_{2}$ solution, and both artificial and natural sea waters equilibrated with either calcite or aragonite. All experiments were conducted at atmospheric $\mathrm{CO}_{2}(\mathrm{~g})$ pressure. Mineral surface areas were taken into consideration, and solid/solution ratios varied from 0.1 to $10 \mathrm{~g} / \mathrm{l}$. Mineral phases used were synthetic calcite and aragonite, three biogenic carbonates, and a natural carbonate sediment roughly characterized as a 50/50 mix of biogenic aragonite and $\mathrm{Mg}$-calcite. 
Preliminary experiments indicated that $99 \%$ of the initial $\mathrm{Am}^{3+}$ was removed from solution within a few minutes to hours. Desorption experiments involved dilution of the above suspensions with Am-free solutions. Less than one percent desorption of previously sorbed $\mathrm{Am}^{3+}$ was measured. The rate of $\mathrm{Am}^{3+}$ adsorption was directly proportional to the initial dissolved $\mathrm{Am}^{3+}$ concentration: at higher concentrations faster rates were observed. $\mathrm{Am}^{3+}$ sorption rates were not directly proportional to the solid/solution ratio, but they approximately followed the square root of the surface area-to-volume ratio.

The effect of $\mathrm{Am}^{3+}$ surface concentration on the extent of adsorption was determined using ten successive spikes of $\mathrm{Am}^{3+}$ added at 30 -minute intervals. A total addition of $10^{-8.15} \mathrm{M}$ of $\mathrm{Am}^{+3}$ was added to a $5 \mathrm{~g} / \mathrm{l}$ calcite suspension. The extent of adsorption after each addition was $99 \%$ within 30 minutes. Thus, over the concentrations studied, there was no measurable influence of surface concentration on the extent of adsorption. This behavior indicated that equivalent reactive surface sites either were not saturated or that an americium phase precipitated.

Adsorption rates onto aragonite were 40 times faster than onto calcite when normalized for surface area. Experiments at similar $\mathrm{Am}^{3+}$ concentrations and solid/solution ratios including $\mathrm{NaCl}$ and/or $\mathrm{MgCl}_{2}$ indicated that epitaxial differences accounted for $15 \%$ of the increased rate, whereas the presence of $\mathrm{Mg}^{2+}$ accounted for the remaining $85 \%$ of the adsorptive difference between calcite and aragonite in sea water.

Because of the microporous nature of biogenic carbonates, representative surface area characterization was not possible. On a mass basis, the adsorption rate of biogenic $\mathrm{Mg}$-calcites and the calcareous sediment agreed well with that of the synthetic calcites. In contrast, adsorption onto synthetic aragonite was approximately 100 times faster than onto biogenic aragonite.

A K $\mathrm{K}_{\mathrm{D}}$ of $10^{5.30}$ was determined for an initial $\mathrm{Am}^{3+}$ concentration of $10^{-8.48} \mathrm{M}$ and a solid/solution ratio of $5 \mathrm{~g} / \mathrm{l}$. This $\mathrm{K}_{\mathrm{D}}$ value, obtained at a very low concentration and solid/solution ratio, was the lowest determined by this experimental methodology.

Mecherri et al. (1990) conducted a limited study of the interactions of $\mathrm{Nd}($ III) with calcite. Batch experiments at $50^{\circ} \mathrm{C}$ used a solid/solution ratio of $6.67 \mathrm{~g} / \mathrm{l}$. Reaction times varied from five minutes to several weeks. Surface area was determined both optically and by BET gas adsorption.

Sorption increased with increased $\mathrm{Nd}^{3+}$ concentration in solution, to a limiting value of approximately $10^{-4.42} \mathrm{eq} / \mathrm{m}^{2}$. The sorption was described by a modified distribution coefficient: 


$$
\mathrm{K}_{\mathrm{D}}=\left(\frac{\left[\mathrm{Nd}^{3+}\right]_{\text {sorbed }}}{\left[\mathrm{Nd}^{3+}\right]_{\text {solution }}}\right)^{\mathrm{n}}
$$

where $n=0.414$. A value of $n<1$ indicated that sorption affinity was not homogeneous and that affinity decreased with increasing surface saturation. $A K_{D}$ of $10^{3.38}\left(121 / \mathrm{m}^{2}\right)$ was determined for an initial $\mathrm{Nd}^{3+}$ concentration of $10^{-6.48} \mathrm{M}$. Desorption experiments in which the reacted solid was exposed to fresh deionized water were conducted for three hours. The extent of desorption was always below $1 \%$ of the previously sorbed $\mathrm{Nd}$.

Higgo and Rees (1986) examined Am(III) sorption from natural sea water on a calcareous sediment $(65 \%$ calcite, $35 \%$ clays $)$ at $4^{\circ} \mathrm{C}$. Initial $\mathrm{Am}^{3+}$ concentrations were $10^{-10} \mathrm{M}$, and solid/solution ratios ranged from 1 to $600 \mathrm{~g} / \mathrm{l}$. A KD of approximately $10^{6}$ was determined at all solid/solution ratios. At high solid/solution ratios, desorption $\mathrm{K}_{\mathrm{D}}$ values were higher than sorption $K_{D}$ values, indicating that a nonsorbing phase existed in the initial sorption procedure.

Allard (1984) examined Am(III) sorption on a variety of minerals, including an uncharacterized calcite. Initial $\mathrm{Am}^{3+}$ concentrations ranged from $10^{-8.30}$ to $10^{-8.74} \mathrm{M}$. Batch experiments used equilibrated artificial ground water ( $\mathrm{AGW}$ ) and $4 \mathrm{M} \mathrm{NaCl}$ solutions. Solid/solution ratios ranged from 6 to $15 \mathrm{~g} / \mathrm{l}$. $\mathrm{K}_{\mathrm{D}}$ values for Am(III) ranged from $10^{3.85}$ at $\mathrm{pH} 6.5$ to $10^{4.47}$ at $\mathrm{pH} 9$. At $\mathrm{pH} 5$, $\mathrm{K}_{\mathrm{D}}$ values were higher in the $\mathrm{AGW}$ than in the $\mathrm{NaCl}$ solution, but at $\mathrm{pH} 8$ any ionic-strength or salt effects were inconclusive.

Dosch (1979) reported a $K_{D}$ value for Am(III) sorption onto dolomite of $10^{4.34}$ from AGW and $10^{3.41}$ from a halite brine. Dosch and Lynch (1980) reported $K_{D}$ values ranging from $10^{3.30}$ to $10^{4,30}$ for Am(III) sorption onto natural dolomite and protodolomites.

\subsection{Curium $(\mathrm{Cm})$}

Dosch (1979) studied $\mathrm{Cm}$ (III) sorption on natural dolomite and reported $\mathrm{K}_{\mathrm{D}}$ values of $10^{5.04}$ from $\mathrm{AGW}$ and $10^{4.08}$ from a saturated halite brine. Reaction time was 170 days and near-neutral $\mathrm{pH}$ was maintained. 


\subsection{Neptunium (Np)}

Keeney-Kennicutt and Morse (1984) demonstrated that significant adsorption of $\mathrm{NpO}_{2}^{+}$occurs on common carbonate minerals. Because of the relatively short half-life of available Np isotopes, sorption experiments were limited to two days maximum. Solid phases used were synthetic calcite, aragonite, and a natural carbonate sediment containing 15 weight-percent organic material. Initial $\mathrm{NpO}_{2}^{+}$concentrations ranged from $10^{-13}$ to $10^{-4} \mathrm{M}$. Background solutions included deionized water, $0.7 \mathrm{M} \mathrm{NaCl}$, a mixed $0.7 \mathrm{M} \mathrm{NaCl}-\mathrm{MgCl}_{2}$ solution, and both artificial and natural sea waters with $35 \%$ salinity.

The results of this study indicated a more complex behavior of $\mathrm{NpO}_{2}^{+}$than previously thought, and a strong affinity for carbonate surfaces. A variety of factors influenced $\mathrm{NpO}_{2}^{+}$uptake, including the solid's surface characteristics, solution composition, solid/solution ratio, and time of reaction. Adsorption was rapid in all carbonate suspensions. Maximum adsorption occurred within 30 minutes at all initial $\mathrm{NpO}_{2}^{+}$concentrations and solid/solution ratios. At initial $\mathrm{NpO}_{2}^{+}$ concentrations below $10^{-7} \mathrm{M}$, all carbonate minerals exhibited similar adsorptive tendencies and greater than $80 \%$ removal from solution. At higher $\mathrm{NpO}_{2}+$ concentrations, the maximum extent of adsorption dropped rapidly until at approximately $10^{-4} \mathrm{M}$ neptunium, solubility limitations were surpassed and precipitation occurred.

At $\mathrm{NpO}_{2}^{+}$concentrations below $10^{-6} \mathrm{M}$, the rate of adsorption in sea water was significantly slower than in deionized water. In addition, natural sediment adsorbed much more slowly than synthetic aragonite, although the extent of adsorption was very similar. The maximum extent of adsorption on aragonite was slightly greater than on calcite, and adsorption from deionized water was greater than from sea water. The extent of $\mathrm{NpO}_{2}^{+}$adsorption as a function of mineralogy varied most in deionized water at low solid/solution ratios. At higher solid/solution ratios in distilled water, or at any solid/solution ratio in sea water, little difference existed between the extent of adsorption by calcite and aragonite. Desorption experiments exposed aragonite to $\mathrm{NpO}_{2}^{+}$for two hours, after which the supernatant was withdrawn and replaced with an unspiked solution. An initial desorption of 1 to $8 \%$ of previously sorbed $\mathrm{NpO}_{2}^{+}$occurred within one hour; however, most of the $\mathrm{NpO}_{2}^{+}$was resorbed onto the substrate, resulting in little net desorption.

Higgo and Rees (1986) examined the distribution of $\mathrm{Np}(\mathrm{V})$ between a calcareous sediment and sea water. The initial $\mathrm{Np}$ concentration was held constant at $10^{-7.47} \mathrm{M}$ and the solid/solution ratio 
was varied. After a desired reaction time, the suspensions were separated and fresh, unspiked sea water was added to the original sediment to assess desorption characteristics. The sorption of neptunium did not change with varied solid/solution ratios; it yielded a $K_{D}$ value of approximately 103.60. Desorption $K_{D}$ values were approximately the same.

Allard (1984) studied $\mathrm{Np}(\mathrm{V})$ sorption on a variety of minerals, including an uncharacterized calcite. Batch experiments used equilibrated $\mathrm{AGW}$ and $4 \mathrm{M} \mathrm{NaCl}$ solutions. Solid/solution ratios ranged from 6 to $15 \mathrm{~g} / \mathrm{l}$, initial $\mathrm{Np}$ concentrations were approximately $10^{-11} \mathrm{M}$, and exposure time was 5 days. $\mathrm{K}_{\mathrm{D}}$ values less than $10^{2.3}$ were found below $\mathrm{pH} 7.5$. With increasing $\mathrm{pH}, \mathrm{K}_{\mathrm{D}}$ values steadily increased, reaching approximately $10^{3.60}$ at $\mathrm{pH}$ 9. Lower $\mathrm{K}_{\mathrm{D}}$ values occurred in the $\mathrm{AGW}$ than in the $\mathrm{NaCl}$ solutions at $\mathrm{pH} 8$, but at $\mathrm{pH} 5$ any salt or ionic strength effects were inconclusive.

Some traditional $K_{D}$ values of approximately $10^{3.70}$ have been reported for $\mathrm{Np}(\mathrm{V})$-carbonate interactions (Ames and Rai, 1978; Harvey, 1981).

\subsection{Plutonium (Pu)}

Higgo and Rees (1986) studied plutonium sorption from sea water by a natural carbonate sediment. No attempt was made to control plutonium oxidation states. An initial Pu concentration of $10^{-9.64} \mathrm{M}$ was reacted with a wide range of solid/solution ratios. The sorption behavior of plutonium was found to be complex. At solid/solution ratios greater than $40 \mathrm{~g} / \mathrm{l}, \mathrm{K}_{\mathrm{D}}$ values ranging from $10^{2.0}$ to $10^{2.3}$ were obtained, and the $\mathrm{Pu}$ was present in oxidized states. Lower solid/solution ratios yielded $\mathrm{K}_{\mathrm{D}}$ values greater than $10^{4.0}$ and the $\mathrm{Pu}$ was present in reduced forms. The low $K_{D}$ values obtained at high solid/solution ratios were accounteu for by the formation of Pu-carbonate solution complexes that sorb less effectively.

Gromov and Spitsyn (1974) investigated the adsorption of plutonium by heterogeneous carbonate bottom sediments in sea water. Sediment surface area was taken into account, temperature ranged from $22-24^{\circ} \mathrm{C}$, and the solid/solution ratio varied from 0.1 to $1.2 \mathrm{~g} / \mathrm{l}$. Preconditioned flasks were stirred vigorously with Pu-spiked sea water and sediment until solution steady state was attained in approximately one hour. The amount of sorption was determined by the change in radioactivity of the solution phase. Sorption isotherms indicated that Pu had at least one sorbable form, likely a $\mathrm{Pu}(\mathrm{OH})_{\mathrm{m}}^{\mathrm{nt}}$. At higher solid/solution ratios the presence of unsorbable forms became apparent, probably due to complexation with carbonate or organic matter. The $K_{D}$ reported for plutonium with the carbonate sediment was $10^{4.04}$. 
Ginzburg and Maksimov (1975) investigated the coprecipitation of Pu(IV) with calcium carbonate. Initial plutonium concentrations varied from $10^{-5}$ to $10^{-9} \mathrm{M}$. Stear.y-state conditions occurred within 30 minutes after the initiation of precipitation. $\mathrm{Pu}(\mathrm{IV})$ entrainment was greatest when a large amount of calcite precipitated. If $\mathrm{Pu}^{4+}$ was introduced into solution after the initiation of calcite precipitation, a much lower percentage of removal occurred. An increase in carbonate ion concentration decreased $\mathrm{Pu}^{4+}$ entrainment by the precipitate in all cases. This decrease could have been due to carbonate complexation in solution, or an artifact of the precipitate crystal form. At high carbonate alkalinities, small spherical aggregates with radial structure formed; lower carbonate alkalinities produced larger rhombohedral crystals. The spherical aggregates were more susceptive to surface sorption, whereas the prismatic crystals incorporated more $\mathrm{Pu}^{4+}$ into the bulk of the crystal.

Dosch (1979) studied plutonium sorption onto dolomite and reported $K_{D}$ values of $10^{3.86}$ from AGW and $10^{3.32}$ from a halite brine. Dosch and Lynch (1980) found similar values for Pu sorption onto natural dolomite and protodolomites; their $K_{\mathrm{D}}$ values ranged from $10^{3.30}$ to $10^{3.85}$.

\subsection{Radium (Ra)}

Gnanapragasam (1991) studied the partitioning of radium between calcium carbonate and solutions slightly supersaturated with respect to calcite, over reaction periods of 8 and 17 weeks. Seeded experiments yielded slightly higher partition coefficients compared to homogeneous nucleation. A logarithmic partition coefficient of $\lambda=10^{-1.89}$ was found to be valid for the range $\left[\mathrm{Ra}^{2+}\right]_{\mathrm{aq}}:\left[\mathrm{Ca}^{2+}\right]_{\mathrm{aq}}=10^{-9}$ to $10^{-6}$ or $[\text { Ra }]_{\text {solid }}[\mathrm{Ca}]_{\text {solid }}=10^{-10}$ to $10^{-8}$. Below an aqueous $\mathrm{Ra}^{2+}: \mathrm{Ca}^{2+}$ ratio of $10^{-9}, \lambda$ increased to an unspecified value.

\subsection{Thorium (Th)}

Carroll et al. (1992) captured BEI images of a thorium-reacted calcite crystal which exhibited thorium-rich regions along rhombohedral cleavage faces. The images provided direct evidence that thorium forms a solid sol ttion with calcite.

Stout and Carroll (in progress) are conducting a rigorous thermodynamic and kinetic study of the Th(IV)-calcite system. 


\subsection{Uranium (U)}

Carroll and Bruno (1991) investigated U(VI)-calcite intrractions within a thermodynamic and kinetic framework. The overall capacity for calcite to remove U(VI) from solution was very small and limited to monolayer coverage in solutions undersaturated with respect to rutherfordite, $\mathrm{UO}_{2} \mathrm{CO}_{3}(\mathrm{~s})$. Less than $2 \%$ of the initial $\mathrm{UO}_{2}^{2+}$ was removed from solution. The limited incorporation of $\mathrm{UO}_{2}^{2+}$ at near-neutral $\mathrm{pH}$ was a result of the formation of uranyl-carbonato complexes and the structure of the $\mathrm{UO}_{2}^{2+}$ complex; the linear structure of the complex is too large to fit into the calcite lattice.

The kinetics of $\mathrm{UO}_{2}^{2+}$-calcite interactions were studied with a thin-film continuous-flow reactor. This device allowed investigation of the interactions as a function of solution composition without disturbing the solid phase, and it simulated the movement of ground water past the mineral phase. Initial $\mathrm{UO}_{2}^{2+}$ concentrations varied from $10^{-4.5}$ to $10^{-2} \mathrm{M}$. $\mathrm{A} \mathrm{CO}_{2}(\mathrm{~g})$ pressure of 0.97 atmospheres and a $10^{-2.30} \mathrm{M} \mathrm{NaHCO}_{3}$ background electrolyte solution were used. The solid phase was reacted with increasingly concentrated input solutions. Filtered samples were taken periodically for analysis over a 40-hour period.

Interactions in the $\mathrm{U}(\mathrm{VI})$-calcite system may be described as the adsorption of $\mathrm{U}(\mathrm{VI})$ at the calcite solution interface:

$$
\mathrm{UO}_{2}^{2+}+\mathrm{CaCO}_{3}(\mathrm{~s}) \leftrightarrow>\mathrm{UO}_{2} \mathrm{CO}_{3}+\mathrm{Ca}^{2+}
$$

and the corresponding mass balance expression:

$$
\mathrm{K}_{\mathrm{ex}}^{*}=\frac{\left\{\mathrm{Ca}^{2+}\right\}\left[>\mathrm{UO}_{2} \mathrm{CO}_{3}\right]}{\left\{\mathrm{UO}_{2}^{2+}\right\}\left\{\mathrm{CaCO}_{3}(\mathrm{~s})\right\}}
$$

where $\left[>\mathrm{UO}_{2} \mathrm{CO}_{3}\right]$ is equal to the mole fraction of $\mathrm{U}(\mathrm{VI})$ at the calcite surface. $\mathrm{K}_{\mathrm{ex}}^{*}$ equaled $10^{-5.12 \pm 0.53}$ and was independent of solution $\mathrm{pH}$.

In a related study, Carroll et al. (1992) investigated the interaction of U(VI) with the calcitesolution interface by using SEM, BEI, and Rutherford backscattering spectroscopy (RBS). Experimental work was conducted at $50^{\circ} \mathrm{C}$ and $\mathrm{CO}_{2}(\mathrm{~g})$ pressures of 0.97 and $0.1 \mathrm{~atm}$. Cleaved 
crystal fragments and powdered calcite were exposed to initial U(VI) concentrations below $10^{-2.64}$ $\mathrm{M}$ in a $10^{-2.30} \mathrm{M} \mathrm{NaHCO}_{3}$ background solution.

Precipitation of a uranium bearing phase occurred only in those solutions supersaturated with respect to rutherfordite, $\mathrm{UO}_{2} \mathrm{CO}_{3}(\mathrm{~s})$. At a $\mathrm{UO}_{2}^{2+}$ concentration of $10^{-3.66} \mathrm{M}$ and $\mathrm{pH} 8$, two different growth morphologies existed: flat, radial growths containing $\mathrm{U}$ - and Catrich bands, and small calcite rhombs. The radial growths presumably began as uranium carbonate nucleated on the surface, and the zoning possibly reflected changes in solution composition during reaction time. At $\mathrm{pH} 4.3$, nearly parallel anastamosing uranium-bearing growths occurred within the calcite surface. RBS analysis of the $\mathrm{pH} 4.3$ sample revealed minimal solid solution at depth, supporting the conclusions of Carroll and Bruno (1991).

Morse et al. (1984) attempted to establish the relation between uranyl speciation and sorption behavior with synthetic calcite and aragonite, two biogenic carbonates, and a carbonate sand (50/50 mix of biogenic aragonite and $\mathrm{Mg}$-calcite). The primary goals of the study were to establish the influences of the mineral phase, solid/solution ratio, solution composition, and initial $\mathrm{UO}_{2}^{2+}$ concentration on sorption.

Initial experiments investigating the extent of uranyl adsorption onto calcite yielded unusual results. $\mathrm{UO}_{2}^{2+}$ adsorbed rapidly and then slowly desorbed back into solution. Simultaneously, a series of solution color changes occurred, indicating changes in $\mathrm{UO}_{2}^{2+}$ complexation behavior. Changing the solid/solution ratio had a minor effect on the extent of adsorption, though the reaction kinetics were approximately proportional to the solid/solution ratio. The extent and kinetics of $\mathrm{UO}_{2}^{2+}$ adsorption on calcite were similar in all solutions, varying by approximately $10 \%$. Biogenic carbonates adsorbed $\mathrm{UO}_{2}^{2+}$ slowly, reflecting their lower effective surface areas. The most significant influence on $\mathrm{UO}_{2}^{2+}$ adsorption was the initial concentration. At initial $\mathrm{UO}_{2}^{2+}$ concentrations below approximately $10^{-5} \mathrm{M}$, little adsorption occurred. With increased $\mathrm{UO}_{2}^{2+}$ concentration, the extent of adsorption increased to nearly $100 \%$, until at uranyl concentrations greater than $10^{-2} \mathrm{M}$, maximum adsorption decreased to less than $20 \%$.

Morse et al. (1984) noted that significant adsorption did not occur until the $\mathrm{UO}_{2}^{2+}$ concentration approached the carbonate alkalinity. This result suggested that adsorption is related to the availability of bicarbonate and carbonate anions in solution for complex formation. The authors suggest that $\mathrm{UO}_{2}^{2+}$ adsorbed initially through the formation of hydroxy-carbonato surface species, 
and when an equilibrium concentration of $\mathrm{HCO}_{3}^{-} / \mathrm{CO}_{3}^{2-}$ was established, the $\mathrm{UO}_{2}^{2+}$ surface complex was removed from the calcite-solution interface by the formation of uranyl-carbonato complexes.

Milton and Brown (1987) examined uranyl sorption by a variety of minerals, including calcite. Synthetic and natural calcite chips were exposed to low ionic strength, $\mathrm{pH} 8.5$ ground water. Initial uranyl concentrations were well below the solubility limit of rutherfordite, $\mathrm{UO}_{2} \mathrm{CO}_{3}(\mathrm{~s})$. Approximately $90 \%$ of the added $\mathrm{UO}_{2}^{2+}$ was quickly adsorbed. Over extended reaction periods, a portion of the initially adsorbed $\mathrm{UO}_{2}^{2+}$ desorbed, eventually reaching a steady state at approximately $70 \%$ adsorption. When desorption was induced by solution replacement, roughly $10 \%$ of the adsorbed $\mathrm{UO}_{2}^{2+}$ desorbed after one day. Desorption continued slowly and no steady state was attained within 145 days. The authors suggest that adsorbed $\mathrm{UO}_{2}^{2+}$ ions were incorporated into the calcite lattice as a solid solution, and the later dissolution of the solid solution controlled the long-term aqueous uranyl concentration.

Kitano and Oomori (1971) investigated the coprecipitation of uranium with various calcium carbonate phases. Uranyl-bearing Mg-poor calcite, $\mathrm{Mg}$-rich calcite, and aragonite were selectively precipitated from calcium bicarbonate solutions by decarboxylation. Controlling the amount of $\mathrm{MgCl}_{2}$ or Na-citrate present in solution determined which carbonate phase precipitated. At measured time intervals, aliquots of the supernatant were withdrawn to determine changes in $\mathrm{pH}$, $\mathrm{Ca}^{2+}$ concentration, and $\mathrm{UO}_{2}^{2+}$ concentration with time. At the end of each experiment, the solid was split into two portions. The first portion was analyzed for chemical composition, and the second portion was analyzed by powder x-ray diffraction (XRD) to identify crystallinity.

Kitano and Oomori (1971) described calcium-uranyl-carbonate coprecipitation with the logarithmic partition coefficient, Equation 3 . For the uranyl-calcite coprecipitate, $\lambda_{\text {calcite ranged }}$ from $10^{-2.0}$ to $10^{-0.7}$. The value of $\lambda_{\text {aragonite }}$ was generally an order of magnitude higher, ranging from $10^{-0.52}$ to $10^{-0}$. The partition coefficients for calcite and aragonite both decreased with increasing calcium carbonate precipitation. Kitano and Oomori explain this trend as an increase in carbonate complexation in solution. As carbonate precipitation increased, $\mathrm{pH}$ and alkalinity also increased and reduced the activity of $\mathrm{UO}_{2}^{2+}$; thus, the partition coefficient decreased. Because $\mathrm{UO}_{2} \mathrm{CO}_{3}(\mathrm{~s})$ is orthorhombic lil:e aragonite, the coprecipitation of uranyl with aragonite was considered in a state of equilibrium, but coprecipitation with calcite was not. The authors speculate that the large $\mathrm{UO}_{2}^{2+}$ cation fit better into the larger aragonite structure, and this accounted for the higher partition coefficients for aragonite. 
The authors explored the thermodynamics of the aragonite- $\mathrm{MgCl}_{2}-\mathrm{NaCl}-\mathrm{UO}_{2}^{2+}$ system in some detail. For the exchange reaction:

$$
\mathrm{UO}_{2}^{2+}+\mathrm{CaCO}_{3}(\mathrm{~s}) \leftrightarrow \mathrm{UO}_{2} \mathrm{CO}_{3}(\mathrm{~s})+\mathrm{Ca}^{2+}
$$

the thermodynamic exchange constant between aragonite and uranyl ions is:

$$
\mathrm{K}_{\mathrm{ex}}=\frac{\left\{\mathrm{Ca}^{2+}\right\}\left\{\mathrm{UO}_{2} \mathrm{CO}_{3}(\mathrm{~s})\right\}}{\left\{\mathrm{UO}_{2}{ }^{2+}\right\}\left\{\mathrm{CaCO}_{3}(\mathrm{~s})\right\}}=\frac{\mathrm{K}_{\mathrm{sp}}(\text { aragonite })}{\mathrm{K}_{\mathrm{sp}}\left(\mathrm{UO}_{2} \mathrm{CO}_{3}\right)}=\frac{10^{-8.22}}{10^{-11.73}}=10^{3.48}
$$

Once uranyl-carbonate complexation was accounted for in the partition coefficient, complete agreement was found between the experimental $\lambda$ and $\mathrm{K}_{\mathrm{ex}}$ values for the aragonite system without $\mathrm{NaCl}$. Significant unexplained differences existed for the same system with $\mathrm{NaCl}$. 


\subsection{TRACE METALS}

Very few controlled thermodynamic or kinetic studies in the actinide-carbonate system were found in the survey of published literature. Therefore, a few studies pertaining to other metalcarbonate systems are discussed here. These studies present the most promising approaches and methods in the literature today. Table 4-1 summarizes the reviewed trace metal-carbonate studies. An additional reference list of trace element-carbonate studies is provided in the appendix.

Table 4-1. Summary of Reviewed Trace Metal-Carbonate Mineral Research

\begin{tabular}{|c|c|c|c|c|c|c|}
\hline Author & Sorbate & Sorbent & $\begin{array}{l}\text { Background } \\
\text { solution }\end{array}$ & $\begin{array}{l}\text { Experiment } \\
\text { type }\end{array}$ & Value & Comments \\
\hline $\begin{array}{l}\text { Zachara et al. } \\
\text { (1991) }\end{array}$ & $\begin{array}{l}\mathrm{Ba}^{2+} \mathrm{Sr}^{2+} \\
\mathrm{Cd}^{2+} \\
\mathrm{Mn}^{2+} \\
\mathrm{Co}^{2+} \\
\mathrm{Ni}^{2+} \\
\mathrm{Zn}^{2+}\end{array}$ & calcite & DI & exchange & $\begin{array}{l}n / \mathrm{a} \\
\mathrm{K}^{*}{ }_{\mathrm{ex}}=10^{3.02} \\
\mathrm{~K}^{*}{ }_{\mathrm{ex}}=1()^{1.31} \\
\mathrm{~K}^{*}{ }_{\mathrm{ex}}=1\left(0^{0.56}\right. \\
\mathrm{K}^{*}{ }_{\mathrm{ex}}=10^{0.51} \\
\mathrm{~K}^{*}{ }_{\mathrm{ex}}=1\left(0^{1.50}\right. \\
10100^{3.00}\end{array}$ & $\mathrm{n} / \mathrm{a}$ \\
\hline $\begin{array}{l}\text { Comans and } \\
\text { Middelburg } \\
\text { (1987) }\end{array}$ & $\begin{array}{l}\mathrm{Cd}, \mathrm{Mn} \\
\mathrm{Zn}, \mathrm{Co}\end{array}$ & calcite & various & $\begin{array}{l}\text { surface } \\
\text { precipiti-tion }\end{array}$ & $\mathrm{n} / \mathrm{a}$ & $\mathrm{n} / \mathrm{i}$ \\
\hline $\begin{array}{l}\text { Davis el al. } \\
\text { (1987) }\end{array}$ & Cd(II) & calcite & $\begin{array}{l}\text { AGiW } \\
0.1 \mathrm{M} \mathrm{NaCl}- \\
\mathrm{MgCl}_{2}\end{array}$ & $\begin{array}{l}\text { exchange } \\
\text { kinetic } \\
\text { partition }\end{array}$ & $\begin{array}{l}D=100^{3.18} \\
K_{\text {ex }}=10^{2.83}\end{array}$ & $\begin{array}{l}\text { Dexperimential } \\
\mathrm{K}_{\text {ex }} \text { calculated }\end{array}$ \\
\hline $\begin{array}{l}\text { Papadopoulos } \\
\text { and Rowell } \\
\text { (1988) }\end{array}$ & $\mathrm{Cd}(\mathrm{II})$ & calcite & $\mathrm{DI}$ & $\begin{array}{l}\text { partition } \\
\text { (surface) }\end{array}$ & $\begin{array}{l}D^{*}=1\left(0^{3.50}\right. \\
K_{\mathrm{ex}}=1\left(0^{3.52}\right.\end{array}$ & $\begin{array}{l}\text { D experimental } \\
\mathrm{K}_{\text {ex }} \text { calculated }\end{array}$ \\
\hline $\begin{array}{l}\text { Stipp et al. } \\
\text { (1992) }\end{array}$ & Cd(II) & calcite & DI & surface & $n / i$ & XPS, I.EED, AES \\
\hline $\begin{array}{l}\text { Zachara et al. } \\
(1988)\end{array}$ & $\ln (\mathrm{II})$ & calcite & DI & exchange & $\begin{array}{c}\mathrm{K}^{*} \mathrm{ex}=10^{1 .(0)} \\
1010^{2.17} \\
\mathrm{~K}_{\mathrm{ex}}=10^{3.52} \\
\end{array}$ & $\begin{array}{l}\text { experimental } \\
\text { calculated }\end{array}$ \\
\hline $\begin{array}{l}\text { Jurinak and } \\
\text { Baluer (1956) }\end{array}$ & $7 n$ & $\begin{array}{l}\text { Calcite } \\
\text { dolomite } \\
\text { Cat- } \\
\text { magnesite }\end{array}$ & $0.01 \mathrm{NaCl}$ & isotherm & $n / a$ & $n / a$ \\
\hline $\begin{array}{l}\text { Zacharat et al. } \\
(1989)\end{array}$ & $7 n$ & calcite & DI & surfice & $n / i$ & $\begin{array}{l}\text { SEM, XPS, XRD, } \\
\text { LDS }\end{array}$ \\
\hline
\end{tabular}

\subsection{Comparative Studies}

Zachara et al. (1991) investigated the sorption of $\mathrm{Ba}^{2+}, \mathrm{Sr}^{2+}, \mathrm{Cd}^{2+}, \mathrm{Mn}^{2+}, \mathrm{Zn}^{2+}, \mathrm{Co}^{2+}$, and $\mathrm{Ni}^{2+}$ onto calcite. Variations in metal properties (such as ionic radius, hydration energy, and end- 
member solubility) influence cation affinity for calcite surfaces and determine the relative contributions of adsorption and precipitation.

Metal cation sorption onto calcite surfaces may be expressed by a surface exchange reaction:

$$
>\mathrm{Ca}+\mathrm{Me}^{2+} \leftrightarrow>\mathrm{Me}+\mathrm{Ca}^{2+}
$$

and the surface exchange constant, $\mathrm{K}_{\mathrm{ex}}^{*}$, is equal to:

$$
\mathrm{K}_{\mathrm{ex}}^{*}=\frac{\left[\mathrm{Ca}^{2+}\right]}{\left[\mathrm{Me}^{2+}\right]}\left\{\frac{\mathrm{X}^{*} \mathrm{Me}}{\mathrm{X}^{*} \mathrm{Ca}}\right\}^{\mathrm{n}}
$$

where $\mathrm{X}^{*}$, the surface mole fraction, equals the amount of sorbed Me divided by $\mathrm{S}_{\mathrm{T}}$, and $\mathrm{n}$ is an empirical constant. When $\mathrm{n}=1$, the sorption isotherms have unit slope, and a single exchange constant may describe the sorption reaction.

Initial trace metal concentrations varied from $10^{-8}$ to $10^{-4} \mathrm{M}$. The adsorbate was an aged synthetic calcite of known surface area. Samples of the same calcite were used for each sorption experiment. Solution $\mathrm{pH}$ ranged from 7.0 to 9.5 at atmospheric pressure of $\mathrm{CO}_{2}(\mathrm{~g})$. A series of ${ }^{45} \mathrm{Ca}^{2+}$ isotopic exchange experiments conducted from $\mathrm{pH} 8.4$ to 9.0 yielded an average surfacesite concentration of $10^{-5.44} \mathrm{~mol} \mathrm{Ca} / \mathrm{g}$.

In solutions undersaturated with respect to pure metal carbonates, significant adsorption of all metals except $\mathrm{Sr}^{2+}$ and $\mathrm{Ba}^{2+}$ was observed. Metal ion sorption increased with increasing $\mathrm{pH}$ and decreasing aqueous $\mathrm{Ca}^{2+}$ maintained by calcite solubility. The sequence of observed sorption preference was $\mathrm{Cd}>\mathrm{Zn} \geq \mathrm{Mn}>\mathrm{Co}>\mathrm{Ni}>\mathrm{Ba} \approx \mathrm{Sr}$. Metals with ionic radii greater than $\mathrm{Ca}^{2+}$ $\left(\mathrm{Ba}^{2+}, \mathrm{Sr}^{2+}\right)$ sorbed weakly, whereas metals with ionic radii smaller than $\mathrm{Ca}^{2+}\left(\mathrm{Cd}^{2+}, \mathrm{Mn}^{2+}\right.$, $\mathrm{Zn}^{2+}, \mathrm{Co}^{2+}, \mathrm{Ni}^{2+}$ ) sorbed strongly and exhibited metal-specific selectivity for the calcite surface. For cations smaller than $\mathrm{Ca}^{2+}$, the extent of adsorption decreased with decreasing ionic radius. Desorption preference correlated well with cation hydration energy. Strongly hydrated cations (such as $\mathrm{Zn}^{2+}, \mathrm{Co}^{2+}$, and $\mathrm{Ni}^{2+}$ ) exhibited $80 \%$ desorption within 8 hours. Cations of lower hydration energy $\left(\mathrm{Cd}^{2+}\right.$ and $\left.\mathrm{Mn}^{2+}\right)$ exhibited only 10 to $25 \%$ desorption.

The sorbates $\mathrm{Cd}^{2+}, \mathrm{Mn}^{2+}, \mathrm{Co}^{2+}$, and $\mathrm{Ni}^{2+}$ exhibited ideal exchange behavior $(\mathrm{n}=1)$ and $\mathrm{K}_{\mathrm{ex}}^{*}$ was calculated to be $10^{3.02}, 10^{1.31}, 10^{0.56}$, and $10^{0.51}$, respectively. $\mathrm{Zn}^{2+}$ behavior differed from the other sorbates $(n=1.86)$ and required exchange constants that varied from $10^{1.5}$ to $10^{3 .()}$, implying that calcite surface sites exhibited heterogeneity in their binding energy with $\mathrm{Zn}^{2+}$. Values of $\mathrm{K}_{\mathrm{ex}}^{*}$ were found to correlate well with ionic radius. The value for $\mathrm{K}_{\mathrm{ex}}^{*}$ decreased as $\mathrm{Me}^{2+}$ radii deviated from the $\mathrm{Ca}^{2+}$ radius. $\mathrm{K}_{\mathrm{ex}}^{*}$ was also found to be directly proportional to pure end- 
member solubility products, which were similar in trend and magnitude to homogeneous partition coefiicients reported by other researchers.

Comans and Middelburg (1987) investigated the sorption of $\mathrm{Cd}^{2+}, \mathrm{Mn}^{2+}, \mathrm{Zn}^{2+}$, and $\mathrm{Co}^{2+}$ on calcite and tested the applicability of the surface precipitation model derived by Farley et al. (1985) for metal oxides. Previous research provided the data for isotherm construction (Jurinak and Bauer, 1956; Kornicker et al., 1985; McBride, 1979; McBride, 1980). Experimental conditions and data reporting varied by author, causing some problems, but with minor assumptions the data fit the model well.

The basis of the surface precipitation model is that adsorbing cations effectively become part of the adsorbent, creating new surface reaction sites for urther adsorption. Adsorption can then occur onto the new sites, incorporating the previously adsorbed cation into the solid. The continuum between adsorption and precipitation may be mathematically modeled as a "BET-like" sorption isotherm for a constant $\mathrm{pH}$. Such an isotherm consists of three parts. At low Me concentrations, surface coverage increases rapidly up to monolayer coverage. With further Me addition, surface coverage remains fairly constant until the onset of precipitation, when surface coverage again increases rapidly as shown in Figure 2-1.

The equation that defines surface coverage, $\Gamma_{\mathrm{Me}}$ (total moles of $\mathrm{Me}^{2+}$ sorbed per mole of total moles $\mathrm{Ca}$ ) is:

$$
\Gamma_{\mathrm{Me}}=\frac{\left[>\mathrm{MeCO}_{3}\right]+\left[\mathrm{MeCO}_{3}(\mathrm{~s})\right]}{\mathrm{CaT}}
$$

This equation was expanded by the use of the pure end-member solubility products, $K_{s p}$, the adsorption constant, $\mathrm{K}_{\text {ads }}$ (see Equation 18), and applicable mass-balance equations (see Equations 20 to 22). The expanded form allowed the construction of sorption isotherms which provided a good fit to the experimental data. The apparent adsorption affinity $\mathrm{Cd}^{2+}>\mathrm{Mn}^{2+}>\mathrm{Zn}^{2+}>\mathrm{Co}^{2+}$ was as expected from the comparison of trace metal ionic radii to $\mathrm{Ca}^{2+}$. 


\subsection{Single Element Studies}

\subsubsection{Cadmium: Studies of the Aqueous Phase}

Davis et al. (1987) described $\mathrm{Cd}^{2+}$ sorption and solid solution formation at calcite surfaces based on observation and analysis of solution compositions. A solid solution consisting of $\mathrm{CdCO}_{3}(\mathrm{~s})$ and $\mathrm{CaCO}_{3}(\mathrm{~s})$ may be described by the exchange of cations between the solid and solution:

$$
\mathrm{Cd}^{2+}+\mathrm{CaCO}_{3}(\mathrm{~s}) \leftrightarrow \mathrm{CdCO}_{3}(\mathrm{~s})+\mathrm{Ca}^{2+}
$$

and the corresponding mass-action expression:

$$
K_{\mathrm{ex}}=\frac{\left\{\mathrm{CdCO}_{3}(\mathrm{~s})\right\}\left\{\mathrm{Ca}^{2+}\right\}}{\left\{\mathrm{CaCO}_{3}(\mathrm{~s})\right\}\left\{\mathrm{Cd}^{2+}\right\}}
$$

which reduces to the solubility-products ratio of the end-member carbonates:

$$
\mathrm{K}_{\mathrm{ex}}=\frac{\mathrm{K}_{\mathrm{sp}}\left(\mathrm{CaCO}_{3}(\mathrm{~s})\right)}{\mathrm{K}_{\mathrm{sp}}\left(\mathrm{CdCO}_{3}(\mathrm{~s})\right)}
$$

From the experimentally determined mole frictions of each component, the homogeneous partition coefficient for the solid solution may be determined:

$$
D=\frac{\left\{\mathrm{Ca}^{2+}\right\} \mathrm{X}_{\mathrm{CuCO}_{3}}}{\left\{\mathrm{Cd}^{2+} \mid \mathrm{X}_{\mathrm{CaCO}_{3}}\right.}
$$

The mole fractions of the pure phases in the solid solution i.re related to the activities of the component solids by:

$$
\begin{aligned}
& \gamma_{\mathrm{CdCO}_{3}} \mathrm{x}_{\mathrm{CdCO}_{3}}=\left\{\mathrm{CdCO}_{3}(\mathrm{~s})\right\} \\
& \gamma_{\mathrm{CaCO}_{3}} \mathrm{x}_{\mathrm{CaCO}_{3}}=\left\{\mathrm{CaCO}_{3}(\mathrm{~s})\right\}
\end{aligned}
$$

If $\gamma_{\mathrm{Ca}^{2+}}=\gamma_{\mathrm{Cd}^{2+}}$ and the mole fraction of $\mathrm{CdCO}_{3}(\mathrm{~s})$ is very small, such that $\gamma_{\mathrm{CaCO}_{3}(\mathrm{~s})}$ approaches unity, then:

$$
\gamma_{\mathrm{CuCO}_{3}(\mathrm{~s})} \mathrm{D}=\mathrm{K}_{\mathrm{ex}}
$$

Therefore, the values of $K_{e x}$ and $D$ will be equal if the solid solution is ideal.

Two synthetic calcites of known purity and surface area were used in the adsorption experiments of Davis et al. (1987). Solution phases were (1) a low ionic strength AGW, and (2) synthetic solutions of $0.1 \mathrm{M}$ ionic strength with varied concentrations of $\mathrm{MgCl}_{2}$ and $\mathrm{NaCl}$. 
The solutions were equilibrated with calcite at seven different $\mathrm{CO}_{2}(\mathrm{~g})$ pressures. Initial dissolved $\mathrm{Cd}^{2+}$ concentrations ranged from $10^{-7}$ to $10^{-6} \mathrm{M}$ and solid/solution ratios were varied with each experiment. $\mathrm{Cd}^{2+}$ activity was controlled by a slight excess of EDTA (ethylene-diaminetetraacetic acid), which, when used in trace quantities, buffered the $\mathrm{Cd}^{2+}$ concentration but had a negligible effect on the activity of $\mathrm{Ca}^{2+}$ or other major cations.

$\mathrm{Cd}^{2+}$ uptake from EDTA-buffered AGW indicated that at least two sorption processes occurred. Step I consisted of an initial rapid reaction that reached completion within 24 hours. Step II was a slow process that did not reach equilibrium within eight days. Step I may be further divided into two parts: step IA refers to the rapid initial uptake, likely due to adsorption of $\mathrm{Cd}^{2+}$ to discrete sites on the calcite surface; step IB represents the diffusion of $\mathrm{Cd}^{2+}$ into a hydrated $\mathrm{CaCO}_{3}(\mathrm{~s})$ layer and progressively slower sorption leading into step II.

The $\mathrm{pH}$ dependence of $\mathrm{Cd}^{2+}$ sorption upon calcite was determined from $\mathrm{pH} 6$ to 8 . Sorption of $\mathrm{Cd}^{2+}$ decreased substantially with increasing $\mathrm{pH}$ over a constant time interval. The decrease in $\mathrm{Cd}^{2+}$ adsorption with increasing $\mathrm{pH}$ is unusual; Davis et al. (1987) explain it by considering the $\mathrm{pH}$ dependence of $\mathrm{Cd}^{2+}$ speciation with EDTA. Addition of $\mathrm{Mg}^{2+}$ at constant $\mathrm{pH}$ and $0.1 \mathrm{M}$ ionic strength caused decreases in both the magnitude of $\mathrm{Cd}^{2+}$ sorption in step $\mathrm{I}$ and the rate of uptake in step II.

Reversibility experiments used two methods: isotopic exchange of ${ }^{109} \mathrm{Cd}$, and EDTA additions. Isotopic exchange experiments consisted of partial replacement of the supernatant with an equivalent volume and strength $\mathrm{Cd}^{2+}$ radiotracer spiked solution. After a short reaction time (longer reaction times did not alter results) the change in radiotracer activity enabled calculation of the rapidly exchangeable fraction of sorbed $\mathrm{Cd}^{2+}$. Much of the $\mathrm{Cd}^{2+}$ sorbed during step I could undergo rapid exchange. However, the isotope-exchange ability of $\mathrm{Cd}^{2+}$ decreased significantly after increased sorption time. This decrease suggested that $\mathrm{Cd}^{2}+$ forms rapidly reversible bonds with surface sites at the beginning of step $I$, and subsequent surface reactions or mass transport into the calcite remove the $\mathrm{Cd}^{2}+$ from this rapidly reversible state.

The release of sorbed $\mathrm{Cd}^{2+}$ after addition of EDTA was compared to the results of studies where EDTA was added at the beginning of the experiment. After EDTA addition to previously unbuffered solutions, partial desorption occurred during the first four hours. The extent of $\mathrm{Cd}^{2+}$ desorption decreased significantly in samples that had aged longer without EDTA. Thus, with increased time before EDTA addition, $\mathrm{Cd}^{2+}$ became less available for release into the aqueous phase. 
The variation in sorption rates between steps I and II suggested that two or more sorption processes were responsible for the removal of $\mathrm{Cd}^{2+}$ from solution. The rate of $\mathrm{Cd}^{2+}$ sorption in step I was solid-diffusion limited, and it appeared to reach completion within 24 hours. After this period, less than $10 \%$ of adsorbed $\mathrm{Cd}^{2+}$ would undergo isotopic exchange, suggesting that much of the $\mathrm{Cd}^{2+}$ had diffused into the solid (or a hydrated surface layer) and exchanged for $\mathrm{Ca}^{2+}$.

A combination of $\mathrm{Cd}^{2+}$ sorption and $\mathrm{Ca}^{2+}$ isotopic exchange data supported the development of a solid solution by an exchange reaction in step II. In a previous experiment, the authors concluded that long-term $\mathrm{Ca}^{2+}$ isotopic exchange (equivalent to step II) was a result of recrystallization. In the presence of $\mathrm{Cd}^{2+}$, recrystallized matter grows as a solid solution rather than as pure calcite. The mole fractions of $\mathrm{CdCO}_{3}$ and $\mathrm{CaCO}_{3}$ in the new crystalline material may be equated with the ratio of the rates of $\mathrm{Cd}^{2+}$ sorption in step 11 and long-term $\mathrm{Ca}^{2+}$ isotopic exchange. This ratio allows calculation of the homogeneous partition coefficient for the new crystalline material. An average value of $D=10^{3.18 \pm(1)} 10$ was found. The difference between this experimental value and the theoretical $K_{e x}$ of $10^{2.83}$ suggested that the solid solution was not ideal and the activity coefficient of the $\mathrm{CdCO}_{3}$ component was less than unity.

Papadopoulos and Rowell (1988) also investigated Cd(II)-calcite interactions. The initial reaction between $\mathrm{Cd}^{2+}$ and $\mathrm{CaCO}_{3}(s)$ surfaces was rapid, especially at low $\mathrm{Cd}^{2}+$ concentrations. In more concentrated solutions close to $\mathrm{CdCO}_{3}(s)$ saturation, a slow process occurred after the initial rapid sorption. The slow process was interpreted as either the precipitation of $\mathrm{CdCO}_{3}$ (slow at low degrees of supersaturation) or the coprecipitation of $\mathrm{CdCO}_{3}(s)$ and $\mathrm{CaCO}_{3}(s)$ during recrystallization.

The homogeneous partition coefficient for the $\mathrm{CaCO}_{3}-\mathrm{CdCO}_{3}$ solid solution can be calculated from the expression:

$$
D=\frac{\left\{\mathrm{Ca}^{2}+\mid X_{\mathrm{CdCO}_{3}}\right.}{\left|\mathrm{Cd}^{2}+\right| X_{\mathrm{CaCO}_{3}}}
$$

Experimental values of D were very small, indicating an exclusion of $\mathrm{Cd}^{2+}$ from the bulk solid. If a two-dimensional solid solution existed and only the surface $C a^{2+}$ atoms were considered, then $\mathrm{X}^{*} \mathrm{CaCO}_{3}$ and $\mathrm{X}^{*} \mathrm{CaCO}_{3}$ represent the surface mole fractions. Using these assumptions at $\mathrm{Cd}^{2+}$ concentrations helow $\mathrm{CdCO}_{3}(s)$ saturation, a surface partition coefficient, $\mathrm{D}^{*}$, with a mean value 
of $10^{3.50}$ was calculated. This value compared well with $K_{e x}$ calculated from the ratio of the solubility products:

$$
\mathrm{K}_{\mathrm{ex}}=\frac{\mathrm{K}_{\mathrm{sp}}\left(\mathrm{CaCO}_{3}\right)}{\mathrm{K}_{\mathrm{sp}}\left(\mathrm{CdCO}_{3}\right)}=\frac{10^{-8.48}}{10^{-12.0}}=10^{3.52}
$$

The similarity of $D^{*}$ and $K_{e x}$ indicated that the solid solution was nearly ideal at the calcite surface.

\subsubsection{Cadmium: Study of the Solid Phase}

Stipp et al. (1992) examined the uptake of $\mathrm{Cd}^{2+}$ by calcite and its subsequent solid-state diffusion into the calcite lattice. The authors made extensive use of surface analysis techniques ( $x$ ray photoelectron spectroscopy [XPS], low energy electron diffraction [LEED], and Auger electron spectroscopy [AES]). In the past, solid-state diffusion was considered unimportant in trace metal uptake from solution. The authors have shown that $\mathrm{Cd}^{2+}$ diffuses into the bulk of the calcite crystal and $\mathrm{Ca}^{2+}$ diffuses outward to form a solid solution.

Cleaved calcite crystal fragments and aged otavite $\left(\mathrm{CdCO}_{3}\right)$ or calcite powders w'se used in the adsorption and precipitation experiments. Single calcite crystals exposed to $\mathrm{Cd}^{2+}$ solutions were swept dry with a stream of high purity $\mathrm{N}_{2}$ gas to avoid evaporation that could leave a residual layer on the surface. Solution compositions were chosen to specifically elicit either adsorption or precipitation. In the first portion of the study, otavite overlayers were precipitated onto calcite chips from a slightly supersaturated cadmium carbonate solution. The precipitated coating was almost pure otavite to a depth of $30 \AA$, as determined by XPS. The Cd:Ca ratio increased from zero on the original calcite to about 65 after two months of reaction. In contrast, the $\mathrm{Cd}$ :Ca ratio on calcite cleavage fragments exposed for 10 months was approximately 3:0, suggesting that over long time periods cadmium moved away from the surface. In the next experiment, a calcite chip with a surface $\mathrm{Cd}: \mathrm{Ca}$ ratio of approximately 65 was stored in a vacuum for one month. During storage the surface $\mathrm{Cd}: \mathrm{Ca}$ ratio decreased to a much lower value. These two experiments supported the hypothesis of solid solution development by solid-state diffusion.

The adsorption of $\mathrm{Cd}^{2+}$ by calcite powder was examined in solutions containing $10^{-6.4} \mathrm{M}$ $\mathrm{Cd}^{2+}, 10^{-2} \mathrm{M} \mathrm{KOH}$, and pure $\mathrm{CO}_{2}(\mathrm{~g})$. Seventy-five pereent of the $\mathrm{Cd}^{2+}$ wals removed from solution after 55 hours, yielding a calculated surface coverage of about one-quarter of a monolayer. If all the cadmium was present at the surface, XPS signals should have shown distinctive cadmium peaks, but none were detected. However, a widening of the calcite peaks indicated that more than 
one structural environment existed in the calcite lattice, which was interpreted as resulting from $\mathrm{Cd}^{2+}$ substitution in the calcite lattice.

Three calcite chips were exposed 10 a $100^{-4} \mathrm{MC} \mathrm{Cd}^{2+}$ solution spiked with a $1109 \mathrm{Cd}^{2+}$ radiotracer at atmospheric $\mathrm{CO}_{2}(\mathrm{~g})$ pressure for 1,10 , and 100 minutes. Scintillation counting of both the solution and the chips indicated an uptake of 1.0, 2.8, and 4.0 monolayers, respectively. One to two days later, surface analyses showed cadmium peaks for all three samples barely above background. Samples with originally higher $\mathrm{Cd}^{2+}$ uptake, when analyzed after longer storage limes, had lower cadmium peak intensity ratios. This result, combined with the results from the calcite powder experiment, provided additional e idence for diffusion of $\mathrm{Cd}^{2+}$ into the bulk calcite crystal.

Stimulated desorption by $x$-ray exposure was used to gain useful information. Four cleavage fragments were exposed for one minute 10 a $10^{-4} \mathrm{MCd}^{2+}$ solution spiked with a Cd-radiotracer. Surface uptake was calculated to be about one monolayer. Two samples were analyzed within an hour of drying, and the other two samples were stored for 24 hours before analysis. The fresher samples lost $30 \%$ of their total cadmium by $x$-ray induced desorption, while samples stored for one day lost only around $12 \%$. This difference demonstrated that the amount of cadmium available for $x$-ray stimulated desorption decreased substantially with time after uptake because the cadmium had moved away from the surface, providing further evidence for cadmium diffusion into the calcite crystal.

\subsubsection{Zinc: Studies of the Aqueous Phase}

Zachara et al. (1988) investigated the surface reaction mechanisms of $\mathrm{Zn}^{2+}$ on calcite. Zine adsorption, desorption, and isotopic exchange were consistent with a reversible surface exchange reaction:

$$
>\mathrm{Ca}^{2+}+\mathrm{Zn} \mathrm{n}^{2+} \rightarrow>7 \mathrm{n}^{2+}+\mathrm{Ca}^{2+}
$$

and the corresponding surface exchange reaction constant, $\mathrm{K}_{\mathrm{ex}}^{*}$ :

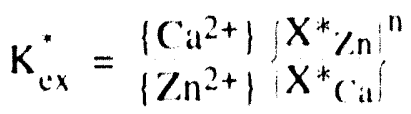

where $X^{*}$, the surface mole fraction, equals the amount of sorbed Me divided by $S_{T}$, and $n$ is an

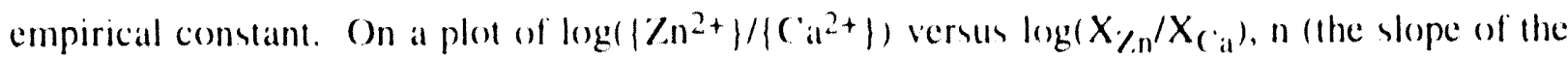


line) equaled 1.69. The charge and speciation of the surface species ( $>\mathrm{Ca}$ or $>\mathrm{Zn}$ ) is unknown. This study viewed adsorption as a free cation bound to an anionic site within the lattice of a surface layer.

Experiments were conducted over various reaction times, $\mathrm{pH}$ values, $\mathrm{CO}_{2}(\mathrm{~g})$ pressures, $\mathrm{Ca}^{2+}$ concentrations, and calcite surface charges. Synthetic $\mathrm{CaCO}_{3}(\mathrm{~s})$ of known surface area and over 99\% purity was the substrate for the adsorption experiments. Equilibrium calcite suspensions ranged over $2.5 \mathrm{pH}$ units at three different $\mathrm{CO}_{2}(\mathrm{~g})$ pressures and a constant ionic strength of 0.1 M. Initial $\mathrm{Zn}^{2+}$ concentrations ranged from $10^{-7}$ to $10^{-4} \mathrm{M}$.

Sorption studies were conducted under conditions undersaturated with respect to the most stable phase, hydrozincite, $\mathrm{Zn}_{5}(\mathrm{OH})_{6}\left(\mathrm{CO}_{3}\right)_{2}(\mathrm{~s})$. Initial removal of $\mathrm{Zn}^{2+}$ from solution was rapid. After approximately 12 hours, sorption either ceased entirely or continued with first order reaction kinetics. The amount of zinc adsorbed was a function of the initial $\mathrm{Zn}^{2+}$ concentration, the substrate surface area, and the calcite used. Sorption increased with increased $\mathrm{pH}$; simultaneously $\mathrm{Ca}^{2+}$ concentrations decreased and carbonate alkalinity increased due to calcite solubility. At any single initial $\mathrm{Zn}^{2+}$ concentration, fractional adsorption increased with increased $\mathrm{pH}$, yielding a $\mathrm{pH}$ edge similar to that of metal oxide adsorption. The majority of linear and $\log -\log$ sorption isotherms displayed a reduction in slope at a surface density of $10^{-6.5}$ to $10^{-6.3} \mathrm{moles}-\mathrm{Zn} / \mathrm{m}^{2}$, which represents an empirical measure of the adsorption maximum.

The extent of desorption depended upon the methodology of solution change. Replacing the electrolyte solution while maintaining the $\mathrm{pH}$ and $\mathrm{Ca}^{2+}$ concentrations caused very limited desorption. Drastic lowering of $\mathrm{pH}$ levels caused complete reversibility by altering the equilibrium of the calcite suspension. $\mathrm{K}_{\mathrm{ex}}$, expressed as the ratio of the solubility products of pure endmember solid phases, is equal to:

$$
\mathrm{K}_{\mathrm{ex}}=\frac{\mathrm{K}_{\mathrm{sp}}\left(\mathrm{CaCO}_{3}\right)}{\mathrm{K}_{\mathrm{sp}}\left(\mathrm{MeCO}_{3}\right)}=10^{2.32}
$$

This value defines a thermodynamic equilibrium constant for solid solution formation or distribution in a solid phase. When a surface-site density of $10^{-5.08} \mathrm{~mol}-\mathrm{Ca} / \mathrm{m}^{2}$ was assumed for calcite (estimated from calcite crystallography) and combined with the adsorption data, the experimental value of $\mathrm{K}_{\mathrm{ex}}^{*}$ was found to be

$$
\mathrm{K}_{\mathrm{ex}}^{*}=\frac{\left\{\mathrm{Ca}^{2+}\right\} \mathrm{X}^{*} \mathrm{Zn}}{\left\{\mathrm{Zn}^{2+}\right\} \mathrm{X}^{*} \mathrm{Ca}} \approx 10^{1.0} \text { to } 10^{2.17}
$$


Because this value was lower than the predicted thermodynamic value, the authors speculated that solubility product ratios may not be good predictors of sorption when surface exchange, rather than coprecipitation, is the mechanism.

Jurinak and Bauer (1956) examined zinc adsorption on calcite, dolomite, and $5.8 \mathrm{~mol}-\% \mathrm{Ca}$ magnesite. Zinc adsorption on calcite decreased with increased temperature, indicating an exothermic reaction. A plateau on the sorption isotherms indicated a region of surface saturation followed by increased adsorption at a $\mathrm{Zn}^{2+}$ concentration of approximately $10^{-5.37} \mathrm{M}$. Because multilayer adsorption of cations is rare, the authors hypothesized that the increased adsorption must be due to a second type of adsorption site.

$\mathrm{Zn}^{2+}$ adsorption on dolomite exhibited no isotherm plateaus indicating site saturation. Additionally, increased temperature caused an increase rather than a decrease in adsorption, indicating an endothermic reaction. Adsorption of $\mathrm{Zn}^{2+}$ by Ca-magnesite was also endothermic, and showed the highest extent of $\mathrm{Zn}^{2+}$ adsorption. Increasing the $\mathrm{Mg}$ content of the sorbent increased the maximum extent of $\mathrm{Zn}^{2+}$ adsorption. The source of adsorptive differences introduced by an increased $\mathrm{Mg}: \mathrm{Ca}$ ratio of the sorbent may have been due to the differing interionic distances in the crystal lattice. It is worth noting that the ionic radii of $\mathrm{Mg}^{2+}$ and $\mathrm{Zn}^{2+}$ are very similar ( 0.78 and $0.83 \AA$, respectively) which suggests the possibility of an exchange reaction.

\subsubsection{Zinc: Study of the Solid Phase}

Zachara et al. (1989) examined the solubility and surface spectroscopy of zinc precipitates on calcite. The precipitation of zinc phases from equilibrium calcite suspensions was investigated to determine if the calcite surface would assist nucleation of zinc solid phases. The presence of calcite was not a requisite for precipitation, though the precipitate was associated with the calcite surface when present. The surface analysis techniques SEM, XPS, XRD, and EDS were used to characterize the surface precipitates. After contact with $10^{-5}$ and $10^{-4} \mathrm{M} \mathrm{Zn}^{2+}$ solutions calculated to be supersaturated with respect to hydrozincite, no visual or spectroscopic evidence of zinc precipitates was found on the calcite surface. The precipitate was either too small to be resolved or was a very thin coating: even at 20,000-x magnification no visible evidence of precipitation existed.

Small, plate-like flecks nucleated on the calcite surface after exposure to $10^{-3} \mathrm{M} \mathrm{Zn}^{2+}$ solutions. EDS analysis confirmed the presence of zinc in the precipitate, and subsequent XRD 
analysis yielded a pattern very similar to hydrozincite. The of $\mathrm{Zn}$-precipitate was less soluble than natural smithsonite, $\mathrm{ZnCO}_{3}(\mathrm{~s})$, and more soluble than natural hydrozincite; the difference was ascribed to unquantifiable structural and hydration differences. The precipitation of hydrozincite appeared to be kinetically favored over smithsonite, which is thermodynamically more stable and isostructural with calcite. 


\subsection{CONCLUSION}

It is apparent from this review that research into actinide-carbonate interactions is embryonic at best. The majority of accessible data is in the form of phenomenological distribution or partition coefficients. Many problems exist in past and present-day experimental design. The use of brines, sea water, etc. is useful for descriptive purposes and application to site-specific storage problems, but it complicates the fundamental understanding of the processes at work by introducing additional variables into an already complex situation. Furthermore, radionuclide solubility, speciation, complexation, and redox response all need to be addressed and integrated into existing geochemical computer codes. Research into the interface geochemistry of $\mathrm{Am}, \mathrm{Nd}, \mathrm{Pu}$, and $\mathrm{U}$, while incomplete, at least is supported by considerable data. Studies of the behavior of $\mathrm{Cm}, \mathrm{Ra}$, and $\mathrm{Th}$ in the geosphere are virtually nonexistent.

The success of geochemical modeling lies in the integration of thermodynamic, kinetic, and surface studies. Exchange models provide a firm theoretical basis, and could easily become a standard for research in coming years. The applications of the surface precipitation and exchange models are the most descriptive and convenient methods for predicting aqueous metal concentrations over a broad range of conditions, providing equilibrium is obtained. The growing use of surface analysis techniques is a very promising aspect of geochemical research. The application of macroscopic techniques (e.g., solution and bulk solid composition) to atomic-scale problems simply does not suffice for a full description of interface chemistry. 


\subsection{REFERENCES}

Allard, B. 1984. "Mechanisms for the Interaction of Am(III) and Np(V) with Geologic Media," Scientific Basis for Nuclear Waste Management VII, Materials Research Society Symposia Proceedings, Boston, MA, November 14-17, 1983. Ed. G.L. McVay. New York, NY: North-Holland. Vol. 26, 899-906.

Ames, L.L., and D. Rai. 1978. Radionuclide Interactions with Soil and Rock Media. EPA 520/6-78-007. Las Vegas, NV: US Environmental Protection Agency, Office of Radiation Programs.

Carroll, S.A. 1993. "Precipitation of Nd-Ca Carbonate Solid Solution at $25^{\circ}$ C," Geochimica Cosmochimica Acta. Vol. 57, No. 14, 3383-3393.

Carroll, S.A., and J. Bruno. 1991. "Mineral-Solution Interactions in the U(VI)- $\mathrm{CO}_{2}-\mathrm{H}_{2} \mathrm{O}$ System," Radiochimica Acta. Vol. 52/53, pt. 1, 187-193.

Carroll, S.A., J. Bruno, J-C. Petit, and J-C. Dran. 1992. "Interactions of U(VI), Nd, and Th(IV) at the Calcite-Solution Interface," Radiochimica Acta. Vol. 58/59, pt. 2, 245-252.

Comans, R.N.J., and J.J. Middelburg. 1987. "Sorption of Trace Metals on Calcite: Applicability of the Surface Precipitation Model," Geochimica et Cosmochimica Acta. Vol. 51, no. 9, 2587-2591.

Davis, J.A., C.C. Fuller, and A.D. Cook. 1987. "A Model for Trace Metal Sorption Processes at the Calcite Surface: Adsorption of $\mathrm{Cd}^{2+}$ and Subsequent Solid Solution Formation," Geochimica et Cosmochimica Acta. Vol. 51, no. 6, 1477-1490.

Dosch, R.G. 1979. "Radionuclide Migration Studies Associated with the WIPP Site in Southern New Mexico," Scientific Basis for Nuclear Waste Management, Proceedings of the Symposium on 'Science Underlying Radioactive Waste Management,' Boston, MA, November 28-December 1, 1978. Ed. G.J. McCarthy. SAND78-1178. New York, NY: Plenum Press. Vol. 1, 395-398.

Dosch, R.G., and A.W. Lynch. 1980. "Radionuclide Transport in a Dolomite Aquifer," Scientific Basis for Nuclear Waste Management, Proceedings of the International Symposium, Boston, MA, November 27-30, 1979. Ed. C.J.M. Northrup, Jr. SAND791016. New York, NY: Plenum Press. Vol. 2, 617-624.

Farley, K.J., D.A. Dzombak, and F.M.M. Morel. 1985. "A Surface Precipitation Model for the Sorption of Cations on Metal Oxides," Journal of Colloid and Interface Science. Vol. 106, no. 1, 226-242.

Franklin, M.L., and J.W. Morse. 1982. "The Interaction of Copper with the Surface of Calcite," Ocean Science and Engineering. Vol. 7, no. 2, 147-174.

Ginzburg, F.L., and V.F. Maksimov. 1975. "Concentration of Plutonium(IV) and Europium by Coprecipitation with Calcium Carbonate," Radiokhimiya. Vol. 17, no. 1, 3-9. 
Gnanapragasam, E.K. 1991. "Solubility Control of Radium by Calcium Precipitates: Experimental Determination and Theoretical Prediction of Partition Coefficients of Radium and Calcium Between the Minerals Gypsum, Brushite, or Calcite and Their Respective Solution." PhD dissertation. Evanston, IL: Northwestern University.

Gromov, V.V., and V.I. Spitsyn. 1974. "Sorption of ${ }^{239} \mathrm{Pu},{ }^{106} \mathrm{Ru}$, and ${ }^{99} \mathrm{Tc}$ by Bottom Sediments in the Pacific Ocean," Radiokhimiya. Vol. 16, no. 2, 157-162.

Harvey, B.R. 1981. "Interstitial Water Studies on Irish Sea Sediments and Their Relevance to the Fate of Transuranic Nuclides in the Marine Environment," Techniques for Identifying Transuranic Speciation in Aquatic Environments, Proceedings of a Technical Committee Meeting on the Behaviour of Transuranics in the Aquatic Environment and SedimentWater Exchanges, Ispra, Italy, March 24-28, 1980. Vienna, Austria: International Atomic Energy Agency. 247-256.

Higgo, J.J.W., and L.V.C. Rees. 1986. "Adsorption of Actinides by Marine Sediments: Effect of the Sediment/Seawater Ratio on the Measured Distribution Ratio," Environmental Science and Technology. Vol. 20, no. 5, 483-490.

Jurinak, J.J., and N. Bauer. 1956. "Thermodynamics of Zinc Adsorption on Calcite, Dolomite, and Magnesite-type Minerals," Soil Science Society of America Proceedings. Vol. 20, 466-471.

Keeney-Kennicutt, W.L., and J.W. Morse. 1984. "The Interaction of $\mathrm{Np}(\mathrm{V}) \mathrm{O}_{2}^{+}$with Common Mineral Surfaces in Dilute Aqueous Solutions and Seawater," Marine Chemistry. Vol. 15, no. $2,133-150$

Kitano, Y., and T. Oomori. 1971. "The Coprecipitation of Uranium with Calcium Carbonate," Journal of the Oceanographic Society of Japan. Vol. 27, no. 1, 34-42.

Kornicker, W.A., J.W. Morse, and R.N. Damasceno. 1985. "The Chemistry of $\mathrm{CO}^{2+}$ Interaction with Calcite and Aragonite Surfaces," Chemical Geology. Vol. 53, no. 3/4, 229236.

Lorens, R.B. 1981. "Sr, Cd, Mn, and Co Distribution Coefficients in Calcite as a Function of Calcite Precipitation Rate," Geochimica et Cosmochimica Acta. Vol. 45, no. 4, 553-561.

McBride, M.B. 1979. "Chemisorption and Precipitation of $\mathrm{Mn}^{2+}$ at $\mathrm{CaCO}_{3}$ Surfaces," Soil Science Society of America Journal. Vol. 43, no. 4, 693-698.

McBride, M.B. 1980. "Chemisorption of $\mathrm{Cd}^{2+}$ on Calcite Surfaces," Soil Science Society of America Journal. Vol. 44, no. 1, 26-28.

McIntire, W.L. 1963. "Trace Element Partition Coefficients-A Review of Theory and Applications to Geology," Geochimica et Cosmochimica Acta. Vol. 27, no. 12, 1209. 1264.

Mecherri, O.M., P. Budiman-Sastrowardoyo, J-C. Rouchaud, and M. Fedoroff. 1990. "Study of Neodymium Sorption on Orthose and Calcite for Radionuclide Migration Modelling in Groundwater," Radiochimica Acta. Vol. 50, no. 3, 169-175. 
Milton, G.M., and R.M. Brown. 1987. "Adsorption of Uranium from Groundwater by Common Fracture Secondary Minerals," Canadian Journal of Larth Sciences. Vol. 24, no. 7, 1321 1328.

Morse, J.W., P.M. Shanbhag, A. Saito, and G.R. Choppin. 1984. "Interaction of Uranyl Ions in Carbonate Media," Chemical Geology. Vol. 42, no. 1/4, 85-99.

Novak, C.F. 1992. An Evaluation of Radionuclide Batch Sorption Data on Culebra Dolomite for Aqueous Compositions Relevant to the Human Intrusion Scenario for the Waste Isolation Pilot Plant. SAND91-1299. Albuquerque, NM: Sandia National Laboratories.

Papadopoulos, P., and D.L. Rowell. 1988. "The Reactions of Cadmium with Calcium Carbonate Surfaces," Journal of Soil Science. Vol. 39, no. 1, 23-36.

Parks, G.A. 1990. "Surface Energy and Adsorption at Mineral Water Interfaces," MineralWater Interface Geochemistry. Eds. M.F. Hochella, Jr. and A.F. White. Reviews in Mineralogy 23. 133-176.

Pingitore, N.E., Jr. 1986. "Modes of Coprecipitation of $\mathrm{Ba}^{2+}$ and $\mathrm{Sr}^{2+}$ with Calcite," Geochemical Processes at Mineral Surfaces, Chicago, IL, September 8-13, 1985. Eds. J.A. Davis and K.F. Hayes. ACS Symposium Series 323. Washington, DC: American Chemical Society. 574-586.

Shanbhag, P.M., and J.W. Morse. 1982. "Americium Interaction with Calcite and Aragonite Surfaces in Seawater," Geochimica et Cosmochimica Acta. Vol. 46, no. 2, 241-246.

Smith, R.W. 1990. "Calculated Partitioning of Americium(III) Into Calcite: An Example of Trivalent Cation Substitution in Rhombohedral Carbonates," Abstracts with Programs, Geological Society of America, Dallas, TX, October 29-November 1, 1990. A261.

Stipp, S.L., M.F. Hochella, Jr., G.A. Parks, and J.O. Leckie. 1992. "C( ${ }^{2+}$ Uptake by Calcite, Solid-State Diffusion, and the Formation of Solid-Solution: Interface Processes Observed with Near-Surface Sensitive Techniques (XPS, LEED, and AES)," Geochimica et Cosmochimica Acta. Vol. 56, no. 5, 1941-1954.

Wang, Y., and E. Merino. 1992. "Dynamic Model of Oscillatory Zoning of Trace Elements in Calcite: Double Layer, Inhibition, and Self-Organization," Geochimica et Cosmochimica Acta. Vol. 56, no. 2, 587-596.

Wersin, P., L. Charlet, R. Karthein, and W. Stumm. 1989. "From Adsorption to Precipitation: Sorption of $\mathrm{Mn}^{2+}$ on $\mathrm{FeCO}_{3}(\mathrm{~s})$, , Geor himica et Cosmochimica Acta. Vol. 53, no. 11, 2787-2796.

Zachara, J.M., J.A. Kittrick, and J.B. Harsh. 1988. "The Mechanism of $\mathrm{Zn}^{2+}$ Adsorption on Calcite," Geochimica et Cosmochimica Acta. Vol. 52, no. 9, 2281-2291.

Zachara, J.M., J.A. Kittrick, L.S. Dake, and J.B. Harsh. 1989. "Solubility and Surface Spectroscopy of Zinc Precipitates on Calcite," Geochimica et Cosmochimica Acta. Vol. 53, no. $1,9-19$. 
Zachara, J.M., C.E. Cowan, and C.T. Resch. 1991. "Sorption of Divalent Metals on Calcite," Geochimica et Cosmochimica Acta. Vol. 55, no. 6, 1549-1562. 


\section{APPENDIX A: BIBLIOGRAPHY OF ACTINIDE SPECIATION, COMPLEXATION, AND SOLUBILITY STUDIES}


A-2 


\section{Bibllography of Actinide Speciation, Complexation, and Solubility Studies}

Allard, B., H. Kipatsi, and J.L. Liljenzin. 1980. "Expected Species of Uranium. Neptunium and Plutonium in Neutral Aqueous Solutions," Journal of Inorganic and Nuclear Chemistry. Vol. 42, no. 7, 1015-1027.

Anderson, R.F., M.P. Bacon, and P.G. Brewer. 1982. "Elevated Concentrations of Actinides in Mono Lake," Science. Vol. 216, no. 4545, 514-516.

Brookins, D.G. 1978. "Retention of Transuranic and Actinide Elements and Bismuth at the Oklo Natural Reactor, Gabon: Application of Eh-pH Diagrams," Chemical Geology. Vol. 23, no. 4, 309-323.

Brookins, D.G. 1979. "Thermodynamic Considerations Underlying the Migration of Radionuclides in Geomedia: Oklo and Other Examples," Scientific Basis for Nuclear Waste Management, Proceedings of the Symposium on 'Science Underlying Radioactive Waste Management,' Boston MA, November 28-December 1, 1978. Ed. G.J. McCarthy. New York, NY: Plenum Press. Vol. 1, 355-366.

Bruno, J., I. Casas, I. Grenthe, and B. Lagerman. 1987. "Studies on Metal Carbonate Complexes. 19. Complex Formation in the Th(IV)- $\mathrm{H}_{2} \mathrm{O}-\mathrm{CO}_{2}(\mathrm{~g})$ System," Inorganica Chimica Acta. Vol. 140, no. 1-2, 299-301.

Bruno, J., I. Grenthe, and P. Rnbouch. 1989. "Studies of Metal Carbonate Equilibria. 20. Formation of Tetra(carbonato)uranium(IV) Ion, $\mathrm{U}\left(\mathrm{CO}_{3}\right)_{4}^{4}$, in Hydrogen Carbonate Solutions," Inorganica Chimica Acta. Vol. 158, no. 2, 221-226.

Cleveland, J.M. 1979. "Critical Review of Plutonium Equilibria of Environmental Concern," Chemical Modeling in Aqueous Systems: Speciation, Sorption, Solubility, and Kinetics, Miami Beach, FL, September 11-13, 1978. Ed. E.A. Jenne. ACS Symposium Series 93. Washington, DC: American Chemical Society, 321-338.

Cleveland, J.M., T.F. Rees, and K.L. Nash. 1983. "Plutonium Speciation in Water from Mono Lake, California," Science. Vol. 222, no. 4630, 1323-1325.

Felmy, A.R., D. Rai, and R.W. Fulton. 1990. "The Solubility of $\mathrm{AmOHCO}_{3}(\mathrm{c})$ and the Aqueous Thermodynamics of the System $\mathrm{Na}^{+}-\mathrm{Am}^{3+}-\mathrm{HCO}_{3}^{2-} \mathrm{OH}^{-}-\mathrm{H}_{2} \mathrm{O}, "$ Radiochimica Acta. Vol. 50, no. 4, 193-204.

Kim, J.l., G. Buckau, F. Baumgärtner, H.C. Moon, and D. Lux. 1984. "Colloid Generation and the Actinide Migration in Gorleben Groundwaters," Scientific Basis for Nuclear Waste Management VII. Materials Research Society Symposia Proceedings, Boston, MA, November 14-17, 1983. Ed. G.L. McVay. New York, NY: North-Holland. Vol. 26, 3140 . 
Lagerman, B. O. 1990. "Complex Formation in the Actinoid- $\mathrm{H}_{2} \mathrm{O} \cdot \mathrm{CO}_{2}(\mathrm{~g})$ System." $\mathrm{PhD}$ dissertation. Stockholm, Sweden: Royal Institute of Technology.

Langmuir, D. 1978. "Uranium Solution-Mineral Equilibria at Low Temperatures with Applications to Sedimentary Ore Deposits," Geochimica et Cosmochimica Acta. Vol. 42, no. $6,547-569$.

Langmuir, D., and J.S. Herman. 1980. "The Mobility of Thorium in Natural Waters at Low Temperatures," Geochemica et Cosmochimica Acta. Vol. 44, no. 11, 1753-1766.

Meinrath, G., and J.I. Kim. 1991a. "Solubility Products of Different Am(III) and Nd(III) Carbonates," European Journal of Solid State and Inorganic Chemistry. Vol. 28, 383388.

Meinrath, G., and J.I. Kim. 1991b. "The Carbonate Complexation of the Am(III) Ion," Radiochimica Acta. Vol. 52/53. pt. 1, 29-34.

Nash, K.L., J.M. Cleveland, and T.F. Rees. 1988. "Speciation Patterns of Actinides in Natural Waters: A Laboratory Investigation," Journal of Environmental Radicactivity. Vol. 7, no. 2. $131-157$.

Nelson, D.M., K.A. Orlandini, and W.R. Penrose. 1989. "Oxidation States of Plutonium in Carbonate-Rich Natural Waters," Journal of Environmental Radioactivity. Vol. 9, no. 3, 189-198.

Nitsche, H. 1991. "Solubility Studies of Transuranium Elements for Nuclear Waste Disposal: Principles and Overview," Radiochimica Acta. Vol. 52/53, pt. 1, 3-8.

Olofsson, U., M. Bengtsson, and B. Allard. 1984. "Generation and Transport of Colloidal Triand Tetravalent Actinide Species in Geologic Environments," Scientific Basis for Nuclear Waste Management VII. Materials Research Society Symposia Proceedings, Boston, MA, November 14-17, 1983. Ed. G.L. McVay. New York, NY: North-Holland. Vol. 26, 859-866.

Rai, D., R.J. Serne, and J.L. Swanson. 1980. "Solution Species of Plutonium in the Environment," Journal of Environmental Quality. Vol. 9, no. 3, 417-420.

Ramsay, J.D.F. 1988. "The Role of Colloids in the Release of Radionuclides from Nuclear Waste," Radiochimica Acta. Vol. 44/45, pt. 1, 165-170.

Sanchez A.L. 1983. "Chemical Speciation and Adsorption Behavior of Plutonium in Natural Waters (British Columbia)." PhD dissertation. Seattle, WA: University of Washington.

Silva, R.J. 1984. "The Behavior of Americium in Aqueous Carbonate Systems," Scientific Basis for Nuclear Waste Management VII, Materials Research Society Symposia Proceedings, Boston, MA, November 14-17, 1983. Ed. G.L. McVay. New York, NY: North-Holland. Vol. 26, 875-881. 
APPENDIX B: BIBLIOGRAPHY OF TRACE METAL SORPTION/COPRECIPITATION STUDIES

B-1 


\section{APPENDIX B}

\section{Bibllography of Trace Metal Sorption/Coprecipitation}

Bancroft, G.M., J.R. Brown, and W.S. Fyfe. 1977. "Quantitative X-ray Photoelectron Spectroscopy (ESCA): Studies of Ba2+ Sorption on Calcite," Chemical Geology. Vol. 19. no. 2, 131-144.

Crocket, J.H., and J.W. Winchester. 1966. "Coprecipitation of Zinc with Calcium Carbonate," Geochimica et Cosmochimica Acta. Vol. 30, no. 10, 1093-1109.

Davis, J.A., and K.F. Hayes. 1986. "Geochemical Processes at Mineral Surfaces: An Overview," Geochemical Processes at Mineral Surfaces, Chicago, IL, September 8-13, 1985. Ed. J.A. Davis and K.F. Hayes. ACS Symposium Series 323. Washington, DC: American Chemical Society. 2-18.

Franklin, M.L., and J.W. Morse. 1983. "The Interaction of $\mathrm{Mn}^{2+}$ with the Surface of Calcite in Dilute Solutions and Seawater," Marine Chemistry. Vol. 12, no. 4, 241-254.

Fuller, C.C., and J.A. Davis. 1987. "Processes and Kinetics of $\mathrm{Cd}^{2+}$ Sorption by a Calcareous Aquifer Sand," Geochimica et Cosmochimica Acta. Vol. 51, no. 6, 1491-1502.

House, W.A., and L. Donaldson. 1986. "Adsorption and Coprecipitation of Phosphate on Calcite," Journal of Colloid and Interface Science. Vol. 112, no. 2, 309-324.

Kinsman, D.J.J., and H.D. Holland. 1969. "The Co-precipitation of Cations with $\mathrm{CaCO}_{3}-\mathrm{IV}$. The Co-precipitation of $\mathrm{Sr}^{2+}$ with Aragonite between $16^{\circ}$ and $96^{\circ} \mathrm{C}$," Geochimica et Cosmochimica Acta. Vol. 33, no. 1, 1-17.

Kitano, Y., N. Kanamori, and R. Fujiyoshi. 1978. "Distribution of Cadmium between Calcium Carbonate and Solution. Part 2. 'Ca( $\left.\mathrm{HCO}_{3}\right)+\mathrm{Cd}^{2+}+\mathrm{NaCl}-->$ Carbonate' System," Geochemical Journal. Vol. 12, no. 3, 147-151.

Königsberger, E., R. Hausner, and H. Gamsjäger. 1991. "Solid-Solute Phase Equilibria in Aqueous Solution. V: The System $\mathrm{CdCO}_{3}-\mathrm{CaCO}_{3}-\mathrm{CO}_{2}-\mathrm{H}_{2} \mathrm{O}$," Geochimica et Cosmochimica Acta. Vol. 55, no. 12, 3505-3514

Lahann, R.W., and R.M. Siebert. 1982. "A Kinetic Model for Distribution Coefficients and Application to Mg-calcites," Geochimica et Cosmochimica Acta. Vol. 46, no. 11, 2229 . 2237.

Morse, J.W. 1986. "The Surface Chemistry of Calcium Carbonate Minerals in Natural Waters: An Overview," Marine Chemistry. Vol. 20, no. 1, 91-112.

Mucci, A., and J.W. Morse. 1983. "The Incorporation of $\mathrm{Mg}^{2+}$ and $\mathrm{Sr}^{2+}$ into Calcite Overgrowths: Influences of Growth Rate and Solution Composition," Geochimica et Cosmochimica Acta. Vol. 47, no. 1, 217-233. 
Mucci, A., and J.W. Morse. 1985. "Auger Spectroscopy Determination of the Surface-Most Adsorbed Layer Composition on Aragonite, Calcite, Dolomite, and Magnesite in Synthetic Seawater," American Journal of Science. Vol. 285, no. 4, 306-317.

Nyffeler, U.P., Y-H. Li, and P.H. Santschi. 1984. "A Kinetic Approach to Describe TraceElement Distribution between Particles and Solution in Natural Aquatic Systems," Geochimica et Cosmochimica Acta. Vol. 48, no. 7, 1513-1522.

Perry, D.L. 1986. "Applications of Surface Techniques to Chemical Bonding Studies of Minerals," Geochemical Processes at Mineral Surfaces, Chicago, IL, September 8-13, 1985. Eds. J.A. Davis and K.F. Hayes. ACS Symposium Series 323. Washington, DC: American Chemical Society. 389-402.

Pingitore, N.E., Jr., and M.P. Eastman. 1984. "The Experimental Partitioning of Ba2+ into Calcite," Chemical Geology. Vol. 45, no. 1/2, 113-120.

Pingitore, N.E., Jr., and M.P. Eastman. 1986. "The Coprecipitation of $\mathrm{Sr}^{2+}$ with Calcite at $25^{\circ} \mathrm{C}$ and 1 Atm," Geochimica et Cosmochimica Acta. Vol. 50, no. 10, 2195-2203.

Pingitore, N.E., Jr., M.P. Eastman, M. Sandidge, K. Oden, and B. Freiha. 1988. "The Coprecipitation of Manganese(II) with Calcite: An Experimental Study," Marine Chemistry. Vol. 25, no. 2, 107-120.

Pingitore, N.E., Jr., F.W. Lytle, B.M. Davies, M.P. Eastman, P.G. Eller, and E.M. Larson. 1992. "Mode of Incorporation of $\mathrm{Sr}^{2+}$ in Calcite: Determination by X-ray Absorption Spectroscopy," Geochimica et Cosmochimica Acta. Vol. 56, no. 4, 1531-1538

Sposito, G. 1986. "Distinguishing Adsorption from Surface Precipitation," Geochemical Processes at Mineral Surfaces, Chicago, IL, September 8-13, 1985. Eds. J.A. Davis and K.F. Hayes. ACS Symposium Series 323. Washington, DC: American Chemical Society. 217-228.

Stipp, S.L., and M.F. Hochella, Jr. 1991. "Structure and Bonding Environments at the Calcite Surface as Observed with X-ray Photoelectron Spectroscopy (XPS) and Low Energy Electron Diffraction (LEED)," Geochimica et Cosmochimica Acta. Vol. 55, no. 6, 1723-1736.

Terakado, Y., and A. Masuda. 1988. "The Coprecipitation of Rare-Earth Elements with Calcite and Aragonite," Chemical Geology. Vol. 69, no. 1, 103-110.

Thorstenson, D.C., and L.N. Plummer. 1977. "Equilibrium Criteria for Two-component Solids Reacting with Fixed Composition in an Aqueous Phase--Example: The Magnesian Calcites," American Journal of Science. Vol. 277, no. 9, 1203-1223.

Van Luik, A.E., and J.J. Jurinak. 1979. "Equilibrium Chemistry of Heavy Metals in Concentrated Electrolyte Solution," Chemical Modeling in Aqueous Systems: Speciation, Sorption, Solubility, and Kinetics Miami Beach, FL, September 11-13, 1978. Ed. E.A. Jenne. ACS Symposium Series 93. Washington, DC: American Chemical Society. 683710 .

Vuceta, J., and J.J. Morgan. 1978. "Chemical Modeling of Trace Metals in Fresh Waters: Role of Complexation and Adsorption," Environmental Science and Technology. Vol. 12, no. 12, 1302-1309. 


\section{DISTRIBUTION}

\section{Federal Agencies}

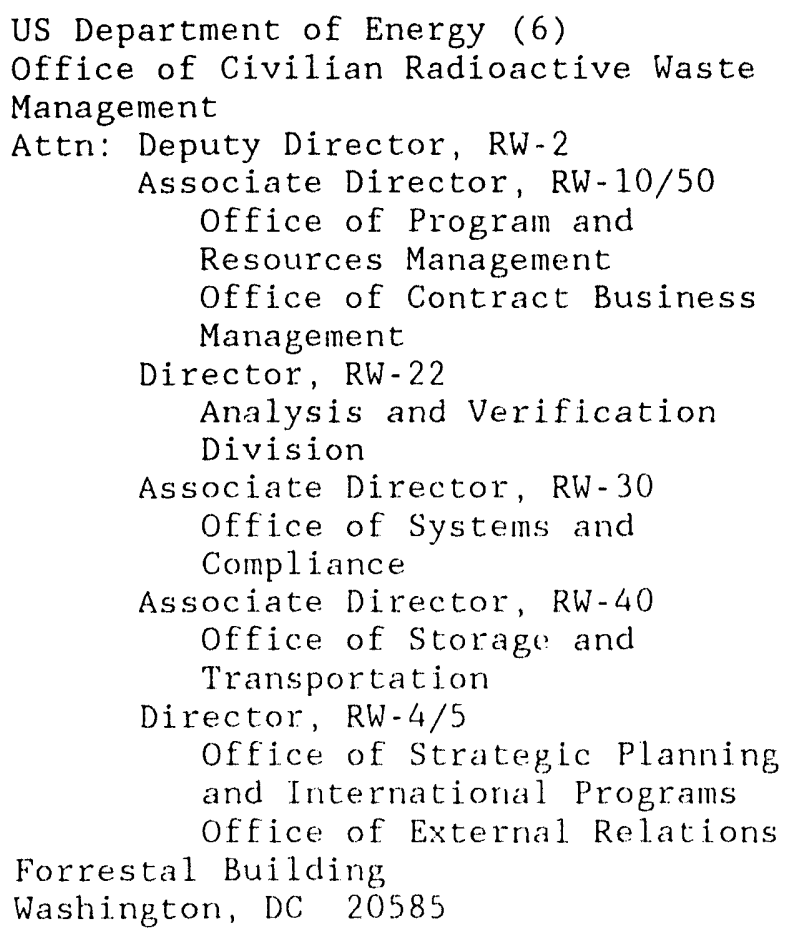

US Department of Energy (3)

WIPP Project Site Office (Carlsbad)

Attn: V. Daub

J. Lippis

J.A. Mewhinney

PO Box 309C

Carlsbad, NM 88221-3090

US Department of Energy

Attn: E. Young

Room E- 178

GAO/RCED/GTN

Washington, DC 20545

US Department of Energy

office of Environmental Restoration and Waste Management

Attn: J. Lytle, EM-30, Trevion II

Washington, DC 20585-0002

US Department of Energy (3)

Office of Environmental Restoration and Waste Management

Attn: M. Frei, EM-34, Trevion II

Washington, DC 20585-0002

US Department of Energy

Office of Environmental. Restoration and Waste Management

Attn: S. Schneider, EM-342, Trevion II

Washington, DC 20585-0002

US Department of Energy (2)

Office of Environment, Safety and $\mathrm{Heal}$ th

Attn: C. Borgstrom, EH-25

R. Pelletier, EH-231

Washington, DC 20585

US Department of Energy (2)

Idaho Operations office

Fuel Processing and Waste?

Management Division

785 DOE Place

Idaho Falls, ID 83402

US Environmental Protection

Agency (2)

Radiat ion Protection Prograns

Attri: M. Oge

ANR -460

Washington, D(; $2(0 / 460$ 
US Geological Survey (2)

Water Resources Division

Attn: R. Livingston

4501 Indian School NE

Suite 200

Albuquerque, NM 87110

US Nuclear Regulatory Comnission Division of Waste Management

Attn: H. Marson

Mail Stop 4-H-3

Washington, DC 20555

\section{Boards}

Defense Nuclear Facilities Safety Board

Attn: D. Winters

625 Indiana Ave. NW, Suite 700

Washington, DC 20004

Nuclear Waste Technical Review

Board (2)

Attn: Chairman

$$
\text { S.J.S. Parry }
$$

1100 Wilson Blvd., Suite 910

Arlington, VA 22209-2297

Advisory Committee on Nuclear Waste

Nuclear Regulatory Commission

Attn: R. Major

7920 Norfolk Ave.

Bethesda, MD 20814

\section{State Agencies}

Environmental Evaluation Group (3) Attn: Library

7007 Wyoming NE

suite F-2

Albuquerque, NM 87109

NM Bureau of Mines and Mineral Resources

Socorro, NM 87801

NM Energy, Minerals, and Natural Resources Department

Attn: Library

2040 S. Pacheco

Santa Fe, NM 87505

NM Environment Department (3)

Secretary of the Environment

Attn: J.Espinosa

1190 St. Francis Drive

Santa $\mathrm{Fe}$, NM 87503-0968
NM Environment Department

WIPP Project Site

Attn: P. McCasland

PO Box 3090

Carlsbad, NM 88221

\section{Laboratories/Corporations}

Battelle Pacific Northwest

Laboratories

Attn: R.E. Westerman, MSIN P8-44

Battelle Blvd.

Richland, WA 99352

INTERA Inc.

Attn: J.F. Pickens

6850 Austin Center Blvd., Suite 300

Austin, TX 78731

INTERA Inc.

Attn: W. Stensrud

PO Box 2123

Carlsbad, NM 88221

IT Corporation

Attn: R.F. Mckinney

Regional office

5301 Central NE, Suite 700

Albuquerque, NM 87108

Lawrence Livermore National

Laboratory (15)

Attn: S.A. Carrol1

Earth Sciences Department

Livermore, CA 94550

Los Alamos National Laboratory

Attn: B. Erdal, INC-12

PO Box 1663

Los Alamos, NM 87544

RE/SPEC, Inc.

Attn: W. Coons

4775 Indian School NE

Suite 300

Albuquerque, NM 87110-3927

RE/SPEC, Inc.

Attn: J.L. Ratigan

PO Box 725

Rapid City, SD 57709

Southwest Research Institute (2)

Center for Nuclear Waste

Regulatory Analys is

Attn: P.K. Nair

6220 Culebra Road

San Antonio, TX 78228-0510 
SAIC

Attn: D.C. Royer

101 Convention Center Dr.

Las Vegas, NV 89109

SAIC

Attn: H.R. Pratt

10260 Campus Point Dr.

San Diego, CA 92121

SAIC (2)

Attn: M. Davis

J. Tollison

2109 Air Park Rd. SE

Albuquerque, NM 87106

Tech Reps Inc. (3)

Attn: J. Chapman

C. Crawford

T. Peterson

5000 Marble NE, Suite 222

Albuquerque, NM 87110

TRW Environmental Safety Systems Attn: L. Wildman

2650 Park Tower Dr., Suite 1300

Vienna, VA 22180-7306

Westinghouse Electric Corporation

Attn: Library

C. Cox

L. Fitch

B.A. Howard

R. Kehrman

PO Box 2078

Carlsbad, NM 88221

Westinghouse-Savannah River

Technology Center (4)

Attn: N. Bibler

J.R. Harbour

M.J. Plodinec

G.G. Wicks

Aiken, SC 29802

\section{National Academy of Sciences,} WIPP Panel

Howard Adler

Oak Ridge Associated Universities

Medical Sciences Division

PO Box 117

Oak Ridge, TN 37831-0117

Fred M. Ernsberger

250 0ld Mill Road

Pittsburgh, PA 15238
Ina Alterman

Board on Radioactive

Waste Management, GF456

2101 Constitution Ave.

Washington, DC 20418

John D. Bredehoeft

Western Region Hydrologist

Water Resources Division

US Geological Survey (M/S 439)

345 Middlefield Road

Menlo Park, CA 94025

Rodney C. Ewing

Department of Geology

University of New Mexico

Albuquerque, NM 87131

Charles Fairhurst, Chairman

Department of $\mathrm{Civil}$ and Mineral Engineering

University of Minnesota

500 Pillsbury Dr. SE

Minneapolis, MN 55455-0220

B. John Garrick

PLG Incorporated

4590 MacArthur Blvd.

Suite 400

Newport Beach, CA 92660-2027

Leonard F. Konikow

US Geological Survey

431 National Center

Reston, VA 22092

Carl A. Anderson, Director

Board on Radioactive Waste Management

National Research Council

HA 456

2101 Constitution Ave. NW

Washington, DC 20418

Jeremiah O'Driscoll

Jody Incorporated

505 Valley Hill Drive

Atlanta, GA 30350

Christopher G. Whipple

Clement International

160 spear St.

Suite 1380

San Francisco, CA 94105 


\section{Individuals}

P. Drez

8816 Cherry Hills Rd. NF.

Albuquerque, NM 87111

D.W. Powers

Star Route Box 87

Anthony, TX 79821

\section{Universities}

University of Missouri-Columbia (15)

Attn: D.L. Stout

Department of Geological Sciences

Columbia, MO 65211

University of New Mexico

Geology Departinent

Attn: Library

Albuquerque, NM 87131

University of Washington

College of Ocean

and Fishery Sciences

Attn: G.R. Heath

583 Henderson Hall

Seattle, WA 98195

\section{Libraries}

Thomas Brannigan Library

Attn: D. Dresp

$106 \mathrm{~W}$. Hadley St.

Las Cruces, NM 88001

Government Publications Department

Zimmerman Library

University of New Mexico

Albuquerque. NM 87131

New Mexico Junior College

Pannell Library

Attn: R. Hill

Lovington Highway

Hobbs, NM 88240

New Mexico State Library

Attn: N. McCallan

325 Don Gaspar

Santa Fe, NM 87503

New Mexico Tech

Martin Speere Memorial Library

Campus Street

Socorro, NM 87810
WIPP Public Reading Room

Carlsbad Public Library

Attn: Director

$101 \mathrm{~S}$. Halagueno St.

Carlsbad, NM 88220

\section{Foreign Addresses}

Studiecentrum Voor Kernenergie

Centre D'Energie Nucleaire

Attn: A. Bonne

SCK/CEN Boeretang 200

B-2400 Mo1, BELGIUM

Atomic Energy of Canada, Ltd. (3)

Whiteshe11 Research Laboratories

Attn: B. Goodwin

M. Stevens

D. Wushke

Pinewa, Manitoba, CANADA ROE 1LO

Francois Chenevier (2)

ANDRA

Route du Panorama Robert Schumann

B.P. 38

92266 Fontenay-aux-Roses, Cedex

FRANCE

Jean-Pierre Olivier

OECD Nuclear Energy Agency

Division of Radiation Protection and Waste Management

38, Boulevard Suchet

75016 Paris, FRANCE

Claude Sombret

Centre D'Études Nucléaires

De La Vallee Rhone

CEN/VALRHO

S.D.H.A. B.P. 171

30205 Bagnols-Sur-Ceze

FRANCE,

Ciesellschaft fur Reaktorsicherheit (GRS) (2)

Attn: B. Baltes

W. Muller

Schwertnergasse 1

D- 5000 Cologne, GERMANY

Bundesanstalt fur Geowissenschaften und Rohstoffe

Attn: M. Langer

Postfach 510153

3000 Hanover 51, GERMANY 
Bundesministerium fur Forschung und Technologie

Postfach 200706

5300 Bonn 2, GERMANY

Institut fur Tieflagerung (2)

Attn: K. Kuhn

Theodor-Heuss-Strasse 4

D-3300 Braunschweig, GERMANY

Physikalisch-Technische Bundesanstalt Attn: P. Brenneke

Postfach 3345

D-3300 Braunschweig, GERMANY

Shingo Tashiro

Japan Atomic Energy Research Inst.

Toka1-Mura, Ibaraki-Ken, 319-11

JAPAN

Netherlands Energy Research

Foundation ECN

Attn: L.H. Vons

3 Westerduinweg

PO Box 1

1755 ZG Petten, THE NETHERLANDS

Svensk Kärnbränsleforsorjning $A B$

Attn: F. Karlsson

Project KBS

Kärnbräns lesakerhet

Box 5864

10248 Stockholm, SWEDEN

Nationale Genossenschaft für die

Lagerung radioaktiver Abfälle (2)

Attn: S. Vomvoris

P. Zuidema

Hardstrasse 73

$\mathrm{CH}-5430$ Wettingen, SWITZERLAND

AEA Technology

Attn: J.H. Rees

D5W/29 Culham Laboratory

Abington, Oxfordshire OX14 3DB

UNITED KINGDOM

AEA Technology

Attn: W.R. Rodwe 11

044/A31 Winfrith Technical Centre

Dorchester, Dorset DT2 8DH

UNITED KINGDOM
AEA Technology

Attn: J.E. Tinson

B4244 Harwel1 Laboratory

Didcot, Oxfordshire OXI1 ORA

UNITED KINGDOM

D.R. Knowles

British Nuclear Fuels, plc

Risley, Warrington, Cheshire WA3 6AS

1002607 UNITED KINGDOM

\section{Internal}

1502

4511

6000

6115

6115

6119

6119

6119

6121

6121

6300

6302

6303

6303

6305

6305

6306

6342

6342

6343

6343

6345

6345

6347

6348

6348

6351

6352

6352

7141

7151

J.C. Cummings

D. P. Garber

D. L. Hartley

P.B. Davies

Staff (15)

F. Gelbard

C.F. Novak (15)

Staff (7)

J.R. Tillerson

Staff (7)

D.E. E11is

L.E. Shephard

S.Y. Pickering

W.D. Weart

S.A. Goldstein

A.R. Lappin

A.L. Stevens

D.R. Anderson

Staff (20)

$V$. Harper-Slaboszewicz

Staff (2)

R.C. Lincoln

Staff (9)

D.R. Schafer

J.T. Holmes

Staff (4)

R.E. Thompson

S.E. Sharpton

WIPP Central Files (10)

Technical Library (5)

Technical Publications

7613-2 Document Processing for DOE/OST I (10)

8523-2 Central Technical Files 

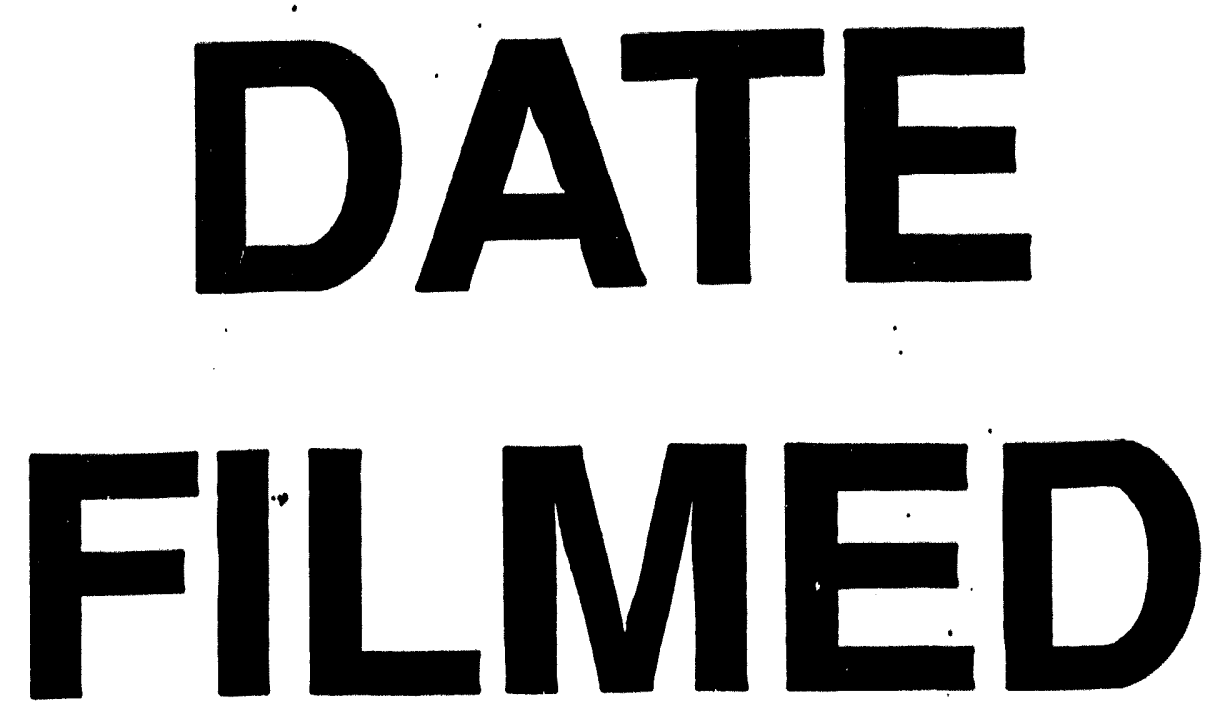

$1 / 11 / 94$
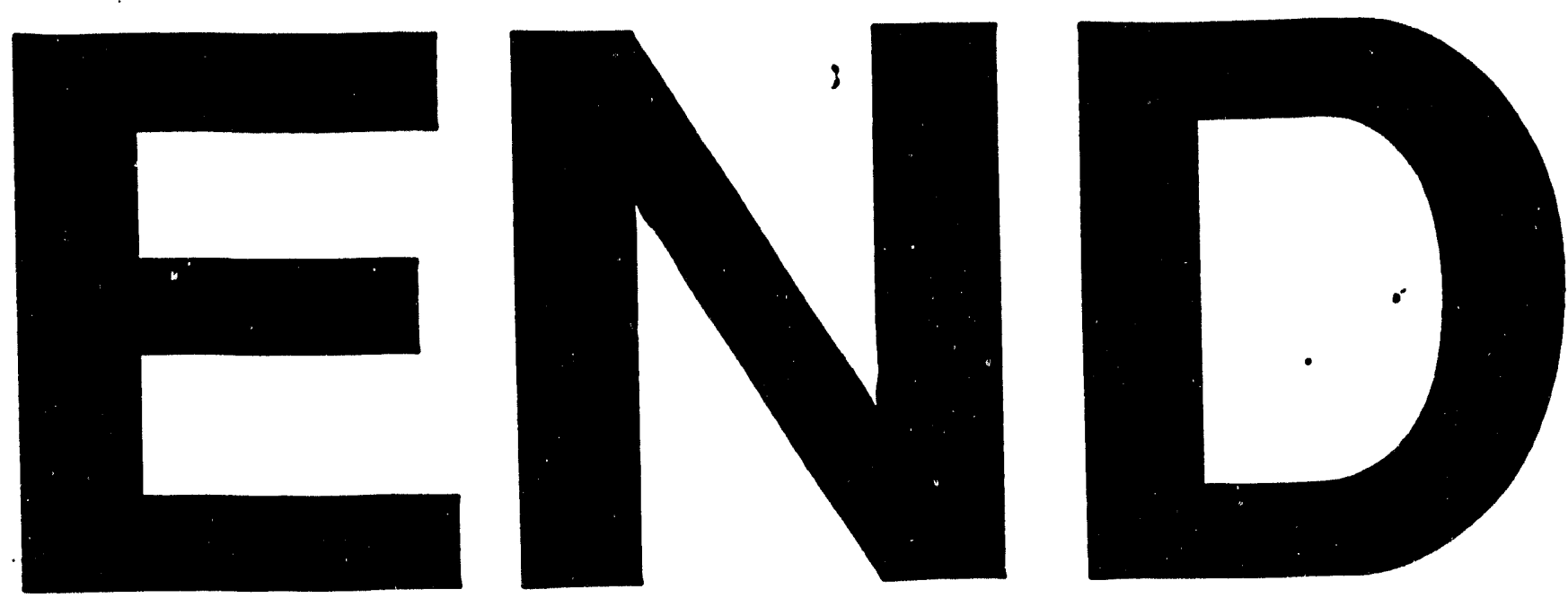
